\title{
KOPCOVITÉ ÚTVARY Z HLÍNY A KAMENE JAKO PROSTŘEDEK K VYMEZENÍ HRANIC ÚZEMÍ V PÍSEMNÝCH PRAMENECH KLÁŠTERA HRADISKO U OLOMOUCE
}

\author{
JAKUB NOVÁK
}

\begin{abstract}
Abstrakt: Do souboru falz kláštera Hradisko, která vznikala v závěru 13. a na počátku 14. století, se řadí šest listin, které detailně popisuji hranice klášterních území na Konicku, Hranicku, Šternbersku, Olomoucku $a v$ lese Velká Střelná. Vedle přirozených hraničních bodi̊ jsou v listinách rovněž zmiňovány takzvané kopce. Tyto objekty byly na Šternbersku rozpoznávány ještě v průběhu 50., 60. a 70. let minulého století, kdy proběhl i doposud na Moravě ojedinělý archeologický výzkum jednoho z hraničních kopcủ. Od té doby jim historiografie nevěnovala bližši pozornost. Ve svém př́spěvku představím výsledky terénni prospekce z let 2017-2019, diky které se podařilo v terénu identifikovat nové a dosud neznámé objekty.
\end{abstract}

Klíčová slova: klášter Hradisko - listiny - hranice - hraniční kopce-terénní prospekce.

Hill-shaped formations of earth and rock as means to determine land borders in the written records of the Hradisko monastery near Olomouc

Abstract: A series of counterfeits from the Hradisko monastery dating from the late 13th century and the early 14th century includes six documents which describe in detail the borders of the monastery holdings in the Konice, Hranice, Šternberk and Olomouc regions, as well as in the Velká Střelná forest. Apart from natural border markers, the documents also mention "hills". These features could be still observed in the Sternberk region in the course of the 1950s, 1960s and 1970s when unique archaeological research into one of the border hills was conducted. Since then they have been marginalized by historiography. The article presents the results of field survey held in 2017-2019, thanks to which it was possible to identify new and unknown features in the landscape.

Key words: Hradisko monastery - documents - borders - border hill-field survey.

\section{Úvod}

Studium hranic patří v současnosti do široce pojatého medievistického diskurzu, který je reprezentován nejen tradičními obory, jakými jsou historie a archeologie, ale řadí se do něho i četná plejáda specializovaných disciplín a úzce vymezených badatelských směrů (výběrově např. Boháč 1974; Teplý 1997; Velímský 1998; Slivka 2004; Dohnal-Šída 2007; Klápště 2012, 199, 204, 219, 223-226, 237; přehledně k dějinám bádání Marková 2017, 9-27; ze středoevropského prostoru lze jmenovat Kiersnowski 1960; Maliniak 2010, 62-76; Modzelewski 2017, 258-269; Šedivý 2018, 126, 212-216). Na hranice kláštera Hradisko u Olomouce ve středověku bylo v tomto ohledu nahlíženo především optikou sledování vývoje majetkových poměrů a analýzy materiálu diplomatické povahy (přehledově Teige 1894; Hawelka 1898; Pinkava 1909; Berger 1915; Hrubý 1947; Šebánek-Dušková 1952; 1953, 1956; Zaoral 1968; Dolista 1971; Štěpán 1986; Bistřický 1993; Elbel 2002; Wihoda 2011).

Soubor písemných pramenů kláštera Hradisko do konce 15. století je složen převážně z listin, jejichž celkový počet přesahuje číslo 150 . Z počtu 32 dokumentů, které se alespoň okrajově věnují vymezování hranic, vyniká zejména šest falz, která velmi detailně popisují hranice klášterních majetků na Šternbersku, Hranicku, Konicku, v blízkém okolí Olomouce a v rozsáhlém území lesa Velká Střelná (obr. 1; přehled písemných pramenů blíže Novák 2019, 9-13). Ačkoli se všechny tyto písemnosti hlásí do průběhu 13. století, jde o dobová falza, jejichž skutečné stáŕí se pohybuje v rozmezí druhé poloviny (závěru) 13. století až poloviny 14. století (viz tab. 1; pro určení datace jednotlivých dokumentů zejména Berger 1915, 161; Šebánek-Dušková 1952, 102; 1953, 264; Schulz-Hosák 1966, 235, 240-241; Hosák 1969, 25-27; Štěpán 1986, 18; Doležel 2003, 149-151; Bolina-Šlézar 2006, 332-333; Wihoda 2011, 139). 


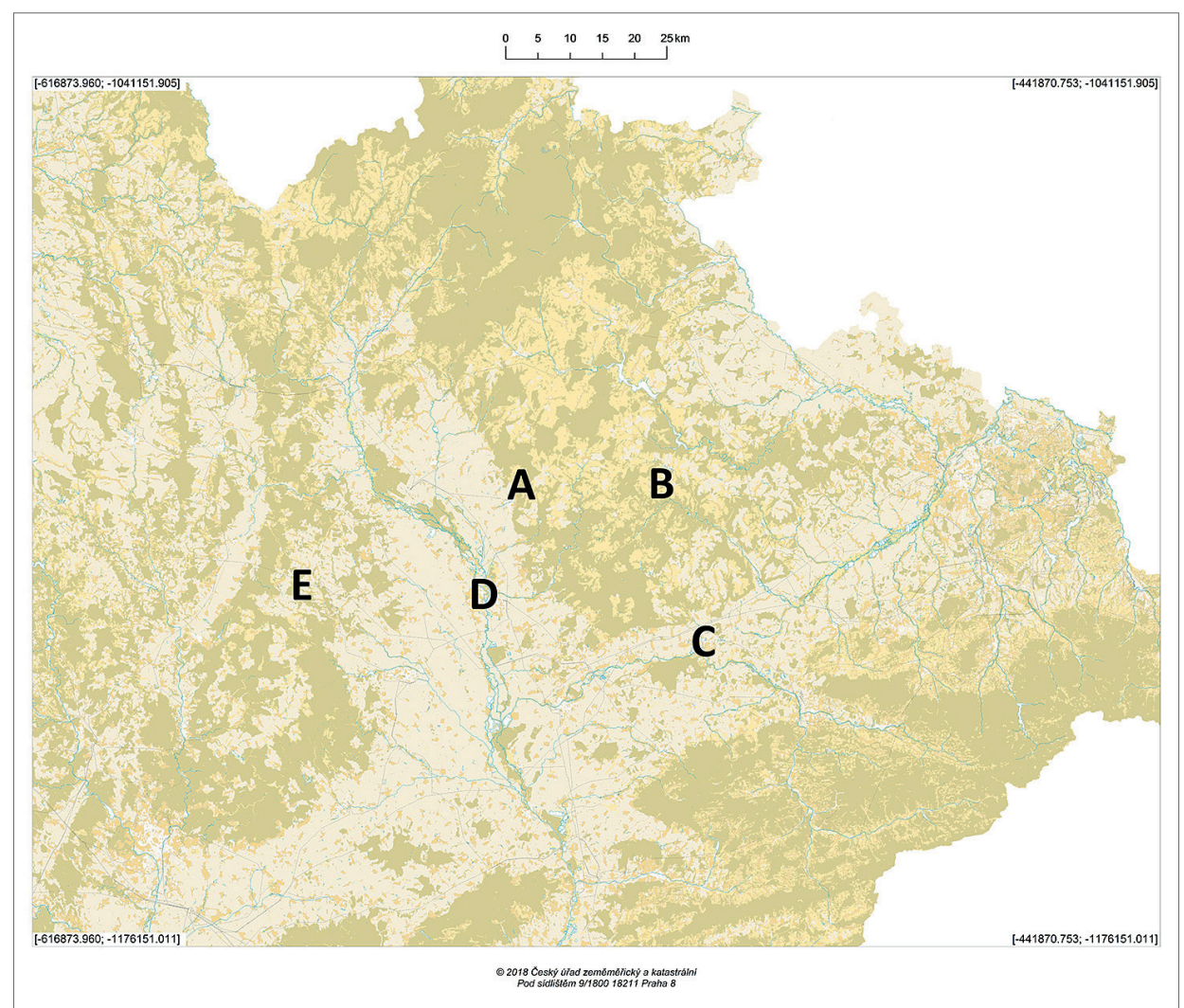

Obr. 1. Zájmové území. A - Šternbersko; B - území lesa Velká Střelná; C - Hranicko; D - Olomoucko; E - Konicko. Vytvořeno autorem pomocí programu https://geoportal.cuzk.cz/geoprohlizec/.

Abb. 1. Interessensgebiete. A - Region Šternberk; B - Gebiet des Großen Střelná-Waldes; C - Region Hranice; D - Region Olmütz; E - Region Konice. Erstellt vom Verfasser mit dem Programm https://geoportal.cuzk.cz/geoprohlizec/.

Vedle přirozených hraničních bodů slouží v listinách ke stanovení průběhu vedení hranice také umělé hraniční body. Jejími nejvýraznějšími reprezentanty jsou především navršené kopce hlíny či kamene. Poprvé byly tyto objekty v rámci regionu střední Moravy blíže zkoumány na Šternbersku v průběhu 50., 60. a 70. let minulého století. Terénní prospekce z let 2017-2019, jejímž cílem bylo rekonstruování průběhu vedení hranic klášterních území, však jasně ukázala, že je stále možné se s hraničními kopci v současné krajině setkat. V předkládané studii nejdříve charakterizuji tyto objekty tak, jak jsou obecně popisovány v písemných pramenech a literatuře. Dále se budu zabývat možnostmi samotné lokalizace a následné deskripce hraničních kopců na územích popsaných v klášterních falzech (blíže k rekonstrukci hranic klášterních území a postupům realizovaného průzkumu terénu Novák 2019, 29-100).

\section{Umělá hraniční znamení - kopce}

Hraniční kopce (acervos, cumulos), někdy v pramenech označované také jako sádky nebo mohyly, tvoří zvláštní skupinu hraničních znamení vytvořených člověkem. Jejich základní popis je možné stanovit již na základě informací obsažených v písemných pramenech středověku a novověku. Ve své podstatě jde o navršené kopce hlíny, někdy také kamene, pokryté travním drnem zabraňujícím 
Tab. 1. Falza kláštera Hradisko, která detailně popisují hranice klášterních majetků na Šternbersku, Hranicku, Konicku, v blízkém okolí Olomouce a v rozsáhlém lese Velká Střelná.

Tab. 1. Fälschungen aus dem Kloster Hradisch, in denen die Grenzen der klösterlichen Besitztümer in den Regionen Šternberk, Hranice, Konice, in der nahen Umgebung von Olmütz und im ausgedehnten Großen Stř̌elná-Wald detailliert beschrieben werden.

\begin{tabular}{|c|c|c|c|c|c|c|}
\hline č. & Datum a místo & Popis pramene & Vydavatel & Edice & Datace & Sledovaná oblast \\
\hline 1. & $\begin{array}{l}\text { 1. } 9.1200 \text {, } \\
\text { Olomouc }\end{array}$ & $\begin{array}{l}\text { Vladislav Jindřich dává klášteru } \\
\text { trhovou ves Knínice u Boskovic } \\
\text { s vesnicemi Šebetovem, Cetko- } \\
\text { vicemi a Uhřicemi i s rozličný- } \\
\text { mi právy a potvrzuje hranice } \\
\text { toho statku. }\end{array}$ & $\begin{array}{l}\text { Vladislav } \\
\text { Jindřich }\end{array}$ & $\begin{array}{l}\text { CDB II, č. } 351, \\
\text { s. } 362-364 .\end{array}$ & $1270-1275$ & $\begin{array}{c}\text { Konicko } \\
\text { (hranice mezi } \\
\text { majetky kláštera } \\
\text { a Alberta z Lešan) }\end{array}$ \\
\hline 2. & $\begin{array}{l}\text { 1. } 9.1201 \\
\text { Olomouc }\end{array}$ & $\begin{array}{l}\text { Vladislav Jindřich klášteru } \\
\text { připisuje trhovou ves Hranice } \\
\text { a prrilehlé vsi a pozemky. }\end{array}$ & $\begin{array}{l}\text { Vladislav } \\
\text { Jindřich }\end{array}$ & $\begin{array}{l}\text { CDB II, č. } 352, \\
\text { s. } 364-368 .\end{array}$ & $\begin{array}{l}\text { počátek } \\
\text { 14. století }\end{array}$ & $\begin{array}{c}\text { Hranicko } \\
\text { (Hranický újezd) }\end{array}$ \\
\hline 3. & $\begin{array}{l}\text { 22. } 2.1203 \text {, } \\
\text { neuvedeno }\end{array}$ & $\begin{array}{l}\text { Vladislav Jindřich daruje kláš- } \\
\text { teru les Střelná. }\end{array}$ & $\begin{array}{l}\text { Vladislav } \\
\text { Jindřich }\end{array}$ & $\begin{array}{l}\text { CDB II, č. } 356, \\
\text { s. } 372-375 .\end{array}$ & $\begin{array}{l}\text { 70. léta } \\
\text { 13. století }\end{array}$ & Les Velká Střelná \\
\hline 4. & $\begin{array}{l}\text { 9. 9. } 1220 \\
\text { Znojmo }\end{array}$ & $\begin{array}{l}\text { Vladislav Jindřich rozhoduje } \\
\text { spor kláštera a lidí markra- } \\
\text { běnky z Lužic ohledně lesa } \\
\text { u Domašova a Lašt’an. }\end{array}$ & $\begin{array}{l}\text { Vladislav } \\
\text { Jindřich }\end{array}$ & $\begin{array}{l}\text { CDB II, č. } 376, \\
\text { s. } 412-415 .\end{array}$ & $\begin{array}{l}\text { závěr 13. až } \\
\text { počátek } \\
\text { 14. století }\end{array}$ & $\begin{array}{c}\text { Šternbersko } \\
\text { (Les u Domašova } \\
\text { a Lašt'an) }\end{array}$ \\
\hline 5. & $\begin{array}{l}\text { 1. } 9.1249, \\
\text { Praha }\end{array}$ & $\begin{array}{l}\text { Václav I. daruje klášteru ves } \\
\text { Hejčín. Určuje její hranice } \\
\text { a dává klášteru rozličná práva. }\end{array}$ & Václav I. & $\begin{array}{l}\text { CDB IV } / 1, \\
\text { č. } 171, \\
\text { s. } 277-282 .\end{array}$ & 1275 & $\begin{array}{l}\text { Olomoucko } \\
\text { (Hejčín) }\end{array}$ \\
\hline 6. & $\begin{array}{l}1269, \\
\text { Praha }\end{array}$ & $\begin{array}{l}\text { Přemysl Otakar II. potvrzuje } \\
\text { rozsudek sporu mezi klášterem } \\
\text { a Albertem a jeho bratry, syny } \\
\text { Zdeslava ze Šternberka, o les } \\
\text { u Domašova a Lašt’an. }\end{array}$ & $\begin{array}{c}\text { Přemysl } \\
\text { Otakar II. }\end{array}$ & $\begin{array}{l}\text { CDB V/2, } \\
\text { č. } 599, \\
\text { s. } 193-195\end{array}$ & $\begin{array}{l}\text { závěr } 13 . \text { až } \\
\text { počátek } \\
\text { 14. století }\end{array}$ & $\begin{array}{c}\text { Šternbersko } \\
\text { (Les u Domašova } \\
\text { a Lašt'an) }\end{array}$ \\
\hline
\end{tabular}

erozi. Proti rozplavení hraničního znamení mohlo pomáhat také obložení dřevěnými trámy. Aby bylo možné takto uměle vytvořené hraničníky odlišit od přirozených nerovností terénu, byla do kopců vkládána znamení - signa oculta, která sloužila jako jednoznačný identifikátor, který potvrzoval, že jde o prostředek určený k vymezení hranice. Předměty, které se záměrně vkládaly do kopců, mohly být např́íklad: kovářská struska, hrnce s uhlím (uhlíky), dřevěné uhlí, cihly, žaludy, sklo, keramické střepy, vápno, mince a různé další kovové předměty (Janiš-Šenkýřová 2004, 196; Šlézar 2007, 158; Marková 2008, 103; 2017, 39-40; Klápště 2012, 223-226; dále také Kiersnowski 1960, 281-282).

Hraniční kopce byly v rámci regionu střední Moravy poprvé popsány badateli, kteří se zabývali možností rekonstrukce vedení průběhu hranice klášterního území známého jako les u Domašova a Lašt’an. V létě roku 1951 prozkoumával terén severovýchodně od Šternberka A. Ferulík. Podařilo se mu dohledat několik hraničních kop přesně v místech uvedených ve falzech. Objekty popsal jako hliněné kopce tvořené z místního materiálu, převážně hlíny, jejichž povrch pokrývá travní drn zabraňující erozi. Autor bohužel blíže nespecifikoval velikost jednotlivých kopců, neuvedl jejich počet a přesněji nepřiblížil ani jejich lokalizaci (Ferulík 1966, 106-109).

Na prospekci A. Ferulíka navázal v létě 1969 a na jaře 1971 J. Prucek. Místa, která jeho předchůdce navštívil před dvaceti lety, totiž právě na přelomu 60. a 70. let 20. století procházela výraznými změnami. Tehdejší státní statky prováděly rozsáhlé kultivační práce, jež spočívaly v nivelizaci členitého terénu a odstraňování hustšího i řidšího lesního porostu. Pruckovým záměrem bylo tedy zachytit aktuální stav dříve identifikovaných hraničních kopců a pozorovat změny, které na nich zanechaly aktivity spojené s kolektivizací a úpravou zemědělské půdy. První, a vlastně jedinou dochovanou hraniční značku - kopec nalezl v souladu se zněním listiny (1269) na nejsevernějším místě údolí potoka Aleš, přibližně $500 \mathrm{~m}$ jižně od kóty 562,2. Upřesnil také 
vzhled samotného kopce, který byl čistě hliněný, bez použití kamení či prsti. Tvarem připomínal mohylu s kruhovou základnou o průměru $5 \mathrm{~m}$ a s vrcholem ve výši $1,5 \mathrm{~m}$. V okolním prostředí působil kopec nápadně a neobvykle. Zjištěné okolnosti dle J. Prucka zcela jednoznačně vylučovaly možnost, že by útvar vznikl později, např́klad při hromadění kamení z okolní obdělané půdy. K možnosti, že by se dochovaly také další hraniční kopce bezprostředně navazující na objekt u pramene potoka Aleš, se vyjádřil negativně. K této domněnce jej vedl zejména fakt, že ležely v terénu, který „byl brzy změněn“. Zda měl na mysli kultivaci půdy již v pozdějším středověku a novověku, nebo změny spojené s kolektivizací intenzivně probíhající od roku 1969, však z jeho sdělení nevyplývá (Prucek 1972, 8-10).

Hraniční kopec lokalizovaný u pramene potoka Aleš byl následně v létě roku 1977 prozkoumán K. Moravem a J. Pruckem zjištovací archeologickou sondou. O této akci se dochovala krátká nálezová zpráva, která jednoznačně lokalizuje místo výskytu hraničního kopce v blízkosti vodoteče (obr. 2). Průměr základny zkoumaného hraničního kopce činil 7 m, výška byla 1,4 m.

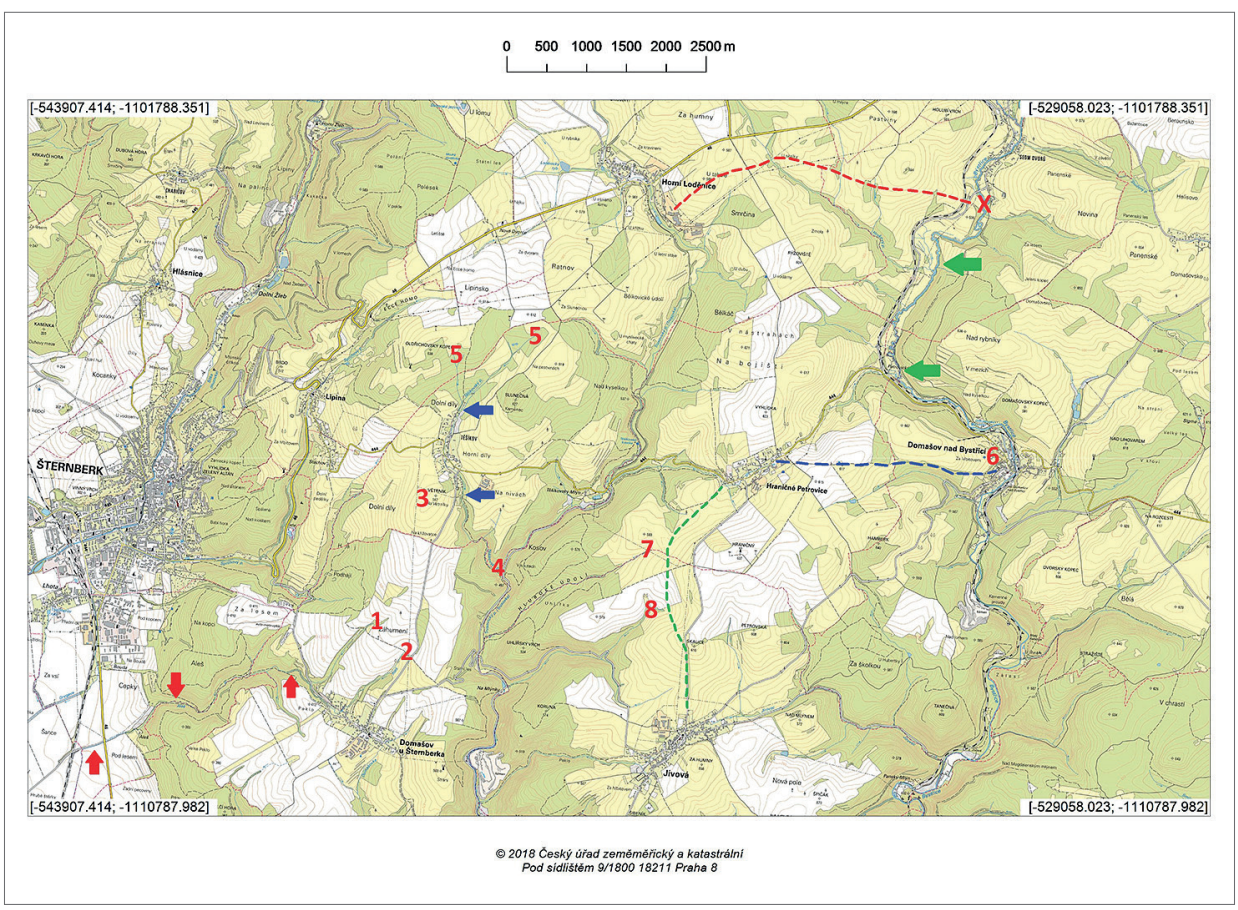

Obr. 2. Severní část území Lesa u Domašova a Lašt’an podle falza 1269 s vyznačenými hraničními body. 1 - hraniční kopec u pramene potoka Aleš; 2 - druhý možný pramen potoka Aleš; 3 - kopec Větrník; 4 - ústí Těšíkovského potoka; 5 -prameny Těšíkovského potoka; 6 - přibližná lokalizace Bychotina pole; 7 - pramen vodoteče (Hluboké údolí), kde A. Ferulík objevil hraniční kopec; 8 - pramen potoka Střelný, kde A. Ferulík objevil hraniční kopec; $\mathbf{X}$ - přibližná lokalizace mostu přes řeku Bystř̌ici; čárkovaně (od Horní Loděnice k symbolu X) - část Rudné cesty; čárkovaně (od č. 6 do Hraniěních Petrovic) - cesta Semita; čárkovaně (od Hraničních Petrovic do Jívové, východně od č. 7 a 8) - Jívovská cesta; šipky (jihozápadně od č. 1 a 2) potok Aleš; šipky (kolem č. 3, 4,5) - tok Těšíkovského potoka; šipky (mezi symbolem X a č. 6) - tok řeky Bystřice. Vytvořeno autorem pomocí programu https://geoportal.cuzk.cz/geoprohlizec/.

Abb. 2. Nördlicher Teil des Gebietes des Waldes bei Domašov und Lašt’any laut der Fälschung von 1269 mit gekennzeichneten Grenzpunkten. 1 - Grenzhügel an der Quelle des Baches Aleš; 2 - zweite mögliche Quelle des Baches Aleš; 3 - Hügel Větrník; 4 - Mündung des Těšíkovský-Baches; 5 - Quellen des Těšíkovský-Baches; 6 - ungefähre Lokalisierung des Feldes Bychotino pole; 7 - Quelle des Wasserlaufs (Tal Hluboké údolí), wo A. Ferulík einen Grenzhügel entdeckte; 8 - Quelle des Baches Střelná, wo A. Ferulík einen Grenzhügel entdeckte; $X$ - ungefähre Lokalisierung einer Brücke über den Fluss Bystřice; gestrichelt (von Horní Loděnice bis zum Symbol X) - Teil der Eisenstraße; gestrichelt (von Nr. 6 bis nach Hraniční Petrovice) - Fußweg Semita; gestrichelt (von Hraniční Petrovice bis nach Jívov, östlich von Nr. 7 und 8) - Jívover Weg; Pfeile (südwestlich von Nr. 1 und 2) - Bach Aleš; Pfeile (um Nr. 3, 4, 5) - Lauf des Těšíkovský-Baches; Pfeile (zwischen dem Symbol X und Nr. 6) Lauf des Flusses Bystřice. Erstellt vom Verfasser mit dem Programm https:/geoportal.cuzk.cz/geoprohlizec/. 
Hlína zásypu byla tmavohnědá, sypká a naprosto odlišná od hlíny okolních polí. V hloubce 1,25 m byla nalezena zlomená podkova a keramický střep se žlutou vnitřní glazurou (obr. 7). Pod tělesem hraničního kopce (hloubka 1,4 m) narazili K. Morav a J. Prucek na původní podklad kory ta vodoteče, který se skládal z černé kompaktní hlíny a usazeného bahna (obr. 6; Dohnal-Morav 1978, 1-2; za poskytnutí nálezové zprávy a dohledání př́íslušných nálezů děkuji Mgr. Lukáši Hlubkovi z Vlastivědného muzea Olomouc).

V oblasti střední Moravy se až do doby průzkumných cest P. Šlézara a K. Faltýnka problematikou umělých hraničních bodů nikdo nezabýval. V rámci terénní prospekce vojenského újezdu Březina a Drahanské vrchoviny narazili v roce 2004 pod Smilovým hradiskem na kamennou mohylku, kterou P. Šlézar ve svém článku interpretoval jako hraniční kopu. Správnost této interpretace podpořil informací z mladšího písemného pramene (1560), který uvádí, že by se v těchto místech měly vyskytovat „staři kopcové, kameni (...)“, a faktem, že samotné Smilovo hradiště vystupuje jako jeden z hraničních bodů v zakládací listině prostějovského augustiniánského kláštera z roku 1391. Mezi místa, kde se pravděpodobně nacházejí další hraniční kopce, řadí rovněž zalesněnou trat' Na zámku na hranici katastrálních území Skřípova a Úsobrna. Tamní kamenné mohyly se dochovaly do výšky minimálně $1,5 \mathrm{~m}$ a byly mylně považovány za zbytky raně středověkého hradiště (Šlézar 2007, 158-159).

Detailnější průzkumy hraničních kopců byly realizovány na území Čech. Skupiny objektů, které odpovídají stanovené definici, se podařilo objevit na katastrálním území obce Nebahovy v okresu Prachatice. Celkem osmnáct mohylovitých kamenných útvarů se zde nacházelo na temeni kopce v nadmořské výšce $835 \mathrm{~m}$. Seskupení leželo uvnitř obdélného prostoru s rozměry $100 \times 200$ m, který vymezovaly valy o výšce dosahující až jednoho metru. Jedna z identifikovaných „mohyl“ byla podrobena archeologickému výzkumu. Měla kruhový až mírně oválný půdorys o průměru necelých $5 \mathrm{~m}$ a výšku $1 \mathrm{~m}$. Během prací bylo zjištěno, že se objekt skládal výhradně z kamenů nahromaděných bez jakýchkoli stop po pravidelném uspořádání. Celou „,mohylu“ pak pokrývala vrstva mechu a jehličí. Spodní kameny přiléhaly ke kamenným plotnám, jež vystupovaly rovnou z podloží. Jediným nálezem, který se podařilo během exkavace objevit, byla část koňského skeletu (Beneš-Lutovský 1997, 219-220).

Mohylovité útvary podobající se hraničním kopcům prozkoumali formou zjištovací sondáže (sondy 1, 2 a 3) v roce 2004 M. Dohnal a P. Šída na katastrálním území obce Šumburk nad Desnou (Dohnal-Šída 2007, 635-652). Objekt v sondě 1 byl založen v polookrouhlé vykopané jámě, která mírnila strmost svahu v okolí. Těleso útvaru tvořily výhradně kameny, které byly pokryty humusovou vrstvou dosahující na vrcholu mohyly mocnosti $5 \mathrm{~cm}$ a ve spodních částech, díky splachům, $30 \mathrm{~cm}$. Uprostřed objektu se nacházela oválná jáma, která obsahovala koncentraci uhlíků. Další uhlíky byly objeveny i mezi kameny do hloubky přibližně $20 \mathrm{~cm}$ ode dna. Nálezy ze sondy 1 dále doplnily jen spálené kosti. Autoři uvádějí, že pokrytí půdním typem (humusovou vrstvou) a zahloubení v centrální části objektu tyto útvary odlišují od hromad kamení vyskytujících se na okrajích polí, tzv. hrobek (Dohnal-Š́ída 2007, 640-643). Mohylovitý útvar ze sondy 2 byl založen v mělké polookrouhlé jámě. Nepatrně mimo střed se nacházela vyhloubená jamka, kolem které byla z nasucho kladených kamenů vyzděna okrouhlá zed'. Autoři předpokládají, že mohla být zastropena dřevem. Na kamennou konstrukci byly následně navršeny kameny, které i zde pokrývala humusová vrstva. Na okrajích objektu se projevil náznak kamenné plenty. Mezi identifikovanými nálezy jasně dominovaly uhlíky, které se hojně vyskytovaly ve vyhloubené jamce. Na jejím okraji byl nalezen také jeden silně zvětralý fragment keramiky. Objekt ze sondy 3 byl založen jen ve velmi mělké polookrouhlé jámě. I zde, stejně jako v předchozích případech, tvořily těleso mohylovitého útvaru zejména kameny, které pokrývala humusová vrstva. Na okrajích objektu se nacházelo nasucho vyzděné kamenné obložení, jež tvořily až $1,5 \mathrm{~m}$ velké kameny. Na dně mezi kamenným obložením byly nasypány uhlíky (Dohnal-Šída 2007, 646).

Z každého objektu byl autory odeslán jeden vzorek na radiokarbonové datování. Nejstarší zjištěné datum pochází z uhlíku ze sondy 1 a spadá do časového intervalu 1390-1450 AD. Uhlík ze sondy 2 byl datován do intervalu 1610-1670 AD a uhlík ze sondy 3 do období 1480-1690 AD 
(Dohnal-Šída 2007, 647). Autoři měli k dispozici také data z jiných mohylovitých útvarů. Radiokarbonové datum $\mathrm{v}$ časovém intervalu 1450-1640 AD pocházelo z objektu, který byl prozkoumán v roce 2004 během výzkumu neolitické lokality Velké Hamry I. Z dalšího objektu, nacházejícího se na katastrálním území Jistebska v podhůří Jizerských hor, pocházelo datum v rozmezí 1480-1650 AD (k tomu blíže Šída-Prostředník 2006, s. 104-120).

\section{Charakteristika hranice mezi majetky kláštera, Konicí a Lešany (Konicko)}

Popisu hranic tohoto území se věnují celkem tři listiny, které pocházejí z druhé poloviny 13. století. První dokument s datem 1. září 1200 je falzum, jež pravděpodobně vzniklo podle nedochované klášterní předlohy mezi lety 1270-1275. Listiny z 26. listopadu 1279 a 1 . prosince 1279 jsou s vysokou pravděpodobností pravé, jejich popis však již nezachycuje tolik detailů jako první listina (CDB II, 362-364 č. 351; CDB VI/1, 127-129 č. 79; CDB VI/1, 129-131 č. 80; k datacím listin blíže Doležel 2003, 149-151; Bolina-Šlézar 2006, 332-333).

Nejstarší z dokumentů (CDB II, 362-364 č. 351) popisuje hranici klášterního majetku následovně: „(...) Prima meta a fluvio, qui vulgo dicitur Studena, ad locum Rachowkop; deinde per directum procedendo usque ad viam publicam, que vida de Gewiczko dirigitur versus Konicz et facit metam usque ad locum, qui vulgo dicitur Sadek; et inde per directum procedendo usque ad locum, qui vulgo dicitur Scalka; postea per directum procedendo usque ad originem fluvii, qui vulgo dicitur Nauirchmalinneho; deinde per directum procedendo usque ad originem fluvii, qui vulgo dicitur Nauirchdestneho, postea directe procedendo usque ad originem fluvii, qui vulgo dicitur Nauirchiauornika. Predictus vero fluvius per descensum facit metam usque ad montem, qui vulgo dicitur Borissow: et sic trans predictum montem directe est eundum usque ad originem fluvii, qui vulgo dicitur Olesni, postea per directum est eundum usque ad locum, qui vulgo dicitur Czastidiel; deinde per directum est eundum usque ad locum, qui vulgo dicitur Bochency; deinde procedendo per directum usque ad locum, qui vulgo dicitur Neopatowem." Zvýrazněny jsou ty části, které odkazují na možný výskyt hraničních kopců.

Snahu obejít uvedené území podle znění listin měl již roku 1687 klášterní inspektor Záblatský. Další pokus o ztotožnění jmenovaných toponym se současnými místy provedl B. Burian. $\mathrm{V}$ průběhu 50. let se $\mathrm{k}$ problematice vrátil okruh badatelů zajímajících se o dějiny severní části Drahanské vrchoviny a Malé Hané - kromě jiných V. Richter, J. Mackerle nebo R. Hikl. Mezi práce mladšího data lze zařadit první díl dvousvazkové monografie vyhodnocující dějiny města Konice od J. Pinkavy a studii J. Pištěláka věnující se Úsobrnu a úsobrnské provincii (Burian 1939; Richter 1955, 48-49; Mackerle 1957, 25; 1958, 23-24; Hikl 1962, 3; Pinkava 1993, 13; Pištělák 2003, 3-4; přehledně k vývoji bádání Bolina-Šlézar 2006).

Důkladný rozbor písemných pramenů, konfrontovaný se závěry dosavadní literatury a doplněný o následnou terénní prospekci uskutečnil zatím jako jediný z badatelů P. Šlézar. Svůj popis doprovází přehlednou mapou, ze které je jednoznačně patrné, že průběh jím interpretované hranice byl ustálen ve směru od říčky Nectavy u Dzbele na severu přes rozvodí Romže a Okluky na jedné straně a Úsobrnky a Bělé na druhé straně až ke katastru obce Suchá v jižní části hranice (Šlézar 2007, 156-157; obr. 3). P. Šlézarovi se mimo jiné podařilo ztotožnit některé obtížně dohledatelné hraniční body. Z hlediska možnosti identifikace hraničních kopců v terénu jsou nejdůležitější především jeho poznatky k interpretaci míst Sadek a Rachowkop. Autor je pokládá na rozdíl od předchozích badatelů za hraniční body umělé, vybudované právě v takových místech, kde jednoznačně interpretovatelné přirozené hranice chyběly (Šlézar 2007, 157-158). Pojem sády (Sadek) má označovat hraniční kameny, které bývaly často usazeny společně ve dvojici s hraničními stromy, nebo na jejich místech, a nesly specifickou značku, případně byly přitesány do určitého tvaru. Název Rachowkop je složeninou, jejiž kořen v podobě slova kop označuje uměle navršené hraniční znamení z hlíny nebo kamení ve tvaru mohyly - takzvané kopce. Složený název pro takto uměle vytvořený útvar býval často odvozen od jména osoby, které zde byly vysázeny kopy pamětní neboli výprask „na pamětnou“ (Šlézar 2007, 158). 


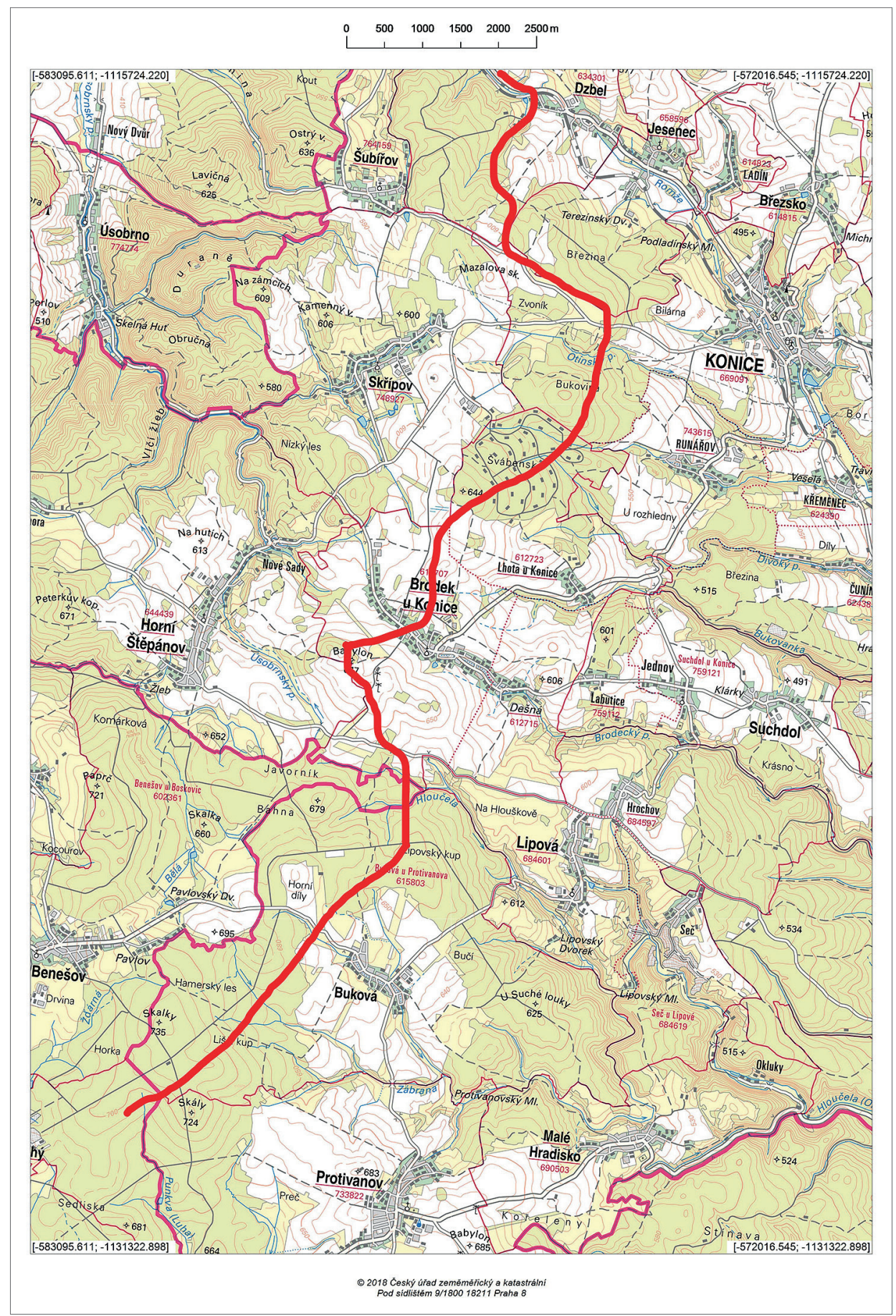

Obr. 3. Průběh hranice mezi majetky kláštera Hradisko, Konicí a Lešany podle Šlézar 2007. Vytvořeno autorem pomocí programu https://geoportal.cuzk.cz/geoprohlizec/.

Abb. 3. Grenzverlauf zwischen den Besitzungen von Kloster Hradisch, Konice und Lešany laut Šlézar 2007. Erstellt vom Verfasser mit dem Programm https://geoportal.cuzk.cz/geoprohlizec/. 
Na uvedené závěry navázal P. Šlézar ještě jednou ve spolupráci s P. Bolinou. Oba autoři přesněji vymezili průběh hranice podle představených listin. Své bádání konfrontovali se závěry prredchozích badatelů a doplnili je o nové poznatky získané zejména studiem starých cest a map (Bolina-Šlézar 2006, 307-342). Upřesněna byla také charakteristika místa Rachowkop, které se nacházelo na tzv. Sládkově skále (kóta 587,6 m). Svým původně jen nevýrazným kupovitým utvářením dokonale splňovalo představu autorů o tom, jak by právě ono hledané místo mělo vypadat. Byly tak vyvráceny předpoklady, které kladly Rachowkop na kopec Hrádky u Úsobrna nebo na vrch Vitočen na kótě 591,5 m (Mackerle 1957, 25; 1958, 23-24; Hik1 1962, 3; Pinkava 1993, 13; Piššlák 2003, 10). Druhý z bodů (Sadek), který má vztah k hraničním kopcům, lokalizovali P. Bolina a P. Šlézar do míst průsečíků silnice č. 366, spojující Šubíŕov a Konici, a čáry, kterou vedli východně od zaniklé vsi Otín a západně od zaniklé Bukoviny (Bolina-Šlézar 2006, 316-318).

\section{Objekty lokalizované v prostoru hranice mezi majetky kláštera, Konicí a Lešany}

V rámci terénní prospekce, která sledovala průběh dělicí linie majetků kláštera, Konice a Lešan, jsem postupoval podle závěrů, které prezentovali P. Šlézar a P. Bolina. Směr linie se podařilo upřesnit především tam, kde bylo možné v terénu identifikovat hraniční kopce.

Sádek (Sadek) se tak pravděpodobně nacházel v místech, kde se na jižním okraji lesa Březina, který utváří rozhraní katastrálních území Jesence a Konice, vyskytuje skupina třinácti kopcovitých útvarů (tab. 2, obj. č. 1-13; obr. 4; obr. 8, 9). Táhlá řada objektů dosahuje délky přibližně $225 \mathrm{~m}$ a výrazně se projevuje na lidarových snímcích i analýze výškopisných dat (obr. 10). Asi 400 m na jih od tohoto místa byly identifikovány na katastrálním území Konice další dva objekty (tab. 2; obj. č. 14, 15), které opět umožnily upřesnit směr hraniční čáry mezi klášterními pozemky a dalšími subjekty.

Dalších šest hraničních kopců bylo dále objeveno na katastrálním území Brodku u Konice (tab. 2; obj. č. 16-21; upozorňují na ně také Geislerová-Parma a kol. 2018, 207-208). Byly soustředěny v okolí vrcholu Babylon (672 m n. m.). Kolem této krajinné dominanty v minulosti probíhala a stále probíhá hranice katastrálního území Brodku u Konice, což se projevuje vyznačením čáry na mapě druhého vojenského mapování i př́itomností novodobých hraničních značek. U jižní hranice k. ú. Brodku u Konice byl identifikován ještě jeden hraniční kopec (tab. 2; obj. č. 22). V jeho blízkosti se nacházejí zdrojnice Okluky, z nichž jedna může být považována za pramen, který je v listině pojmenován jako Nauirchiauornika, tedy Na vrch Javorníka (Pištělák 2003, 10; Bolina-Šlézar 2006, 322-323). O směru vedení hranice tímto směrem tedy nemůže být pochyb. Další dva hraniční kopce (tab. 2; obj. č. 23, 24) byly identifikovány na současném území obce Lipová, přibližně 2 km jihovýchodně od objektů soustředěných kolem kopce Babylon a 800 m východně od značky nalezené u jižní hranice k. ú. Brodku u Konice.

Všechny objevené hraniční kopce byly uměle navršeny z hlíny a kamene. Skupina, ve které materiálově převažoval kámen, sestávala ze čtrnácti zástupců. Ve složení druhé skupiny převládala zejména hlína. Kameny v ní byly sice zastoupeny také, netvořily však př́liš výraznou složku. Objekty, které se skládaly převážně z hlíny, pokrýval travní drn odlišující se od okolní lesní humusové vrstvy. Travní drn zde plnil roli zpevňujícího materiálu, jehož úkolem bylo zabránit erozi. Objekty z kamene pokrývala nejčastěji přirozeně se koncentrující vrstva mechu nebo humusové lesní půdy. Velikostně je možné rozdělit hraniční kopce do dvou kategorií. První se vyznačuje průměrem základny kolem $5 \mathrm{~m}$ a výškou kolem $1,5 \mathrm{~m}$ a druhá průměrem základny 10 až 15 m a výškou 1,8 až 2,2 m. Více zástupců, celkem 17, měla druhá kategorie. Řadí se do ní kopce tvořené kameny i kopce, v nichž převládala hlína (blíže k popisům jednotlivých objektů tab. 2).

\section{Charakteristika hranic lesa u Domašova a Lašt’an (Šternbersko)}

O rozsahu lesa u Domašova a Lašt’an informují celkem dvě listinná falza $(1220,1269)$, jejichž reálné staří je třeba hledat $\mathrm{v}$ rozmezí vymezeném závěrem 13. století na jedné straně a počátkem 
Tab. 2. Katalog lokalizovaných hraničních kopců.

Tab. 2. Katalog der lokalisierten Grenzhügel.

\begin{tabular}{|c|c|c|c|}
\hline Obj. & Oblast/katastrální území & Zeměpisné souřadnice & Popis \\
\hline č. 1 & Konicko/Jesenec & $\begin{array}{l}\mathrm{N} 49^{\circ} 35^{\prime} 27,20^{\prime \prime} \\
\text { a E } 16^{\circ} 51^{\prime} 24,82^{\prime \prime}\end{array}$ & $\begin{array}{l}\text { Objekt tvořen převážně hlínou s menším podílem kamenů do } \\
\text { velikosti } 15 \mathrm{~cm} \text {. Povrch pokrývá travní drn, který se odlišuje } \\
\text { od okolní lesní humusové vrstvy, a náletové dřeviny menší } \\
\text { velikosti. Délka objektu je } 9,5 \mathrm{~m} \text {, výška } 1,5 \mathrm{~m} \text {. Tvarem se } \\
\text { podobá oválu, který je mírně protažený ve směru Z-V. }\end{array}$ \\
\hline č. 2 & Konicko/Jesenec & $\begin{array}{c}\mathrm{N} 49^{\circ} 35^{\prime} 27,48^{\prime \prime} \\
\text { a E } 16^{\circ} 51^{\prime} 23,90^{\prime \prime}\end{array}$ & $\begin{array}{l}\text { Objekt je tvořen převážně hlínou s menším podílem kamenů } \\
\text { do velikosti } 20 \mathrm{~cm} \text {. U jihovýchodní strany umístěn větší } \\
\text { kámen - možný pozůstatek tzv. sádu. Jeho velikost je při- } \\
\text { bližně } 50 \mathrm{~cm} \text {. Výška kopce je } 2,1 \mathrm{~m} \text {, délka } 8 \mathrm{~m} \text {. Základna } \\
\text { objektu opisuje téměř dokonale tvar kruhu. Povrch je pokryt } \\
\text { travním drnem, který se odlišuje od okolní lesní humusové } \\
\text { vrstvy. Na povrchu objektu rostou drobné náletové dřeviny } \\
\text { i vzrostlejší listnaté stromy. }\end{array}$ \\
\hline č. 3 & Konicko/Jesenec & $\begin{array}{l}\text { N } 49^{\circ} 35^{\prime} 27,67^{\prime \prime} \\
\text { a E } 16^{\circ} 51^{\prime} 23,17\end{array}$ & $\begin{array}{l}\text { Objekt je tvořen převážné hlínou a částečně kameny do ve- } \\
\text { likosti } 20 \mathrm{~cm} \text {, méně pak kameny do velikosti } 50 \mathrm{~cm} \text {. Povrch } \\
\text { je pokryt travním drnem, který se odlišuje od okolní lesní } \\
\text { humusové vrstvy. Výška objektu činí } 2,2 \mathrm{~m} \text {, průměr objektu } \\
\text { je } 9 \mathrm{~m} \text {. Kopec má oválný, mírně protáhlý tvar ve směru S-J. } \\
\text { V blízkosti objektu se nacházejí menší snůšky drobných ka- } \\
\text { menů do velikosti } 10 \mathrm{~cm} \text {, které zřejmě pocházejí z blízkého } \\
\text { pole. U severozápadní strany se nachází menší objekt stejné } \\
\text { charakteristiky s výškou } 1 \text { m a průměrem } 2 \mathrm{~m} \text {. }\end{array}$ \\
\hline č. 4 & Konicko/Jesenec & $\begin{array}{c}\mathrm{N} 49^{\circ} 35^{\prime} 27,87^{\prime \prime} \\
\text { a E } 16^{\circ} 51^{\prime} 22,38^{\prime \prime}\end{array}$ & $\begin{array}{l}\text { Objekt je tvořen převážně hlínou a částečně kameny do veli- } \\
\text { kosti } 15 \mathrm{~cm} \text {, ojediněle do velikosti } 30 \mathrm{~cm} \text {. Pokryt je travním } \\
\text { drnem, který se odlišuje od okolní lesní humusové vrstvy. } \\
\text { Na povrchu se dále vyskytují drobné náletové dřeviny. Výš- } \\
\text { ka objektu dosahuje až do } 1,8 \mathrm{~m} \text {, průměr základny je } 8 \mathrm{~m} \text {. } \\
\text { Objekt má oválný tvar, mírně protáhlý ve směru Z-V. }\end{array}$ \\
\hline č. 5 & Konicko/Jesenec & $\begin{array}{l}\mathrm{N} 49^{\circ} 35^{\prime} 28,18^{\prime \prime} \\
\text { a E } 16^{\circ} 51^{\prime} 21,67^{\prime \prime}\end{array}$ & $\begin{array}{l}\text { Objekt je tvořen převážně hlínou a částečně kameny do } \\
\text { velikosti } 15 \mathrm{~cm} \text {, na povrchu je možné najít ojediněle větší } \\
\text { kámen o velikosti } 50 \mathrm{~cm} \text {. Hraniční kopec je nízký, zřejmě již } \\
\text { částečně rozplavený. Tvarem připomíná ovál, mírně pro- } \\
\text { tažený ve směru Z-V. Průměr základny je } 5 \mathrm{~m} \text {, výška } 1 \mathrm{~m} \text {. } \\
\text { Povrch je pokryt travním drnem, který se odlišuje od okolní } \\
\text { lesní humusové vrstvy. }\end{array}$ \\
\hline č. 6 & Konicko/Jesenec & $\begin{array}{l}\mathrm{N} 49^{\circ} 35^{\prime} 28,45^{\prime \prime} \\
\text { a E } 16^{\circ} 51^{\prime} 21,04^{\prime \prime}\end{array}$ & $\begin{array}{l}\text { Objekt je tvořen zejména kameny v rozmezí velikosti } \\
10-15 \mathrm{~cm} \text {, menší podíl tvoř́ také větší kameny do velikosti } \\
50 \mathrm{~cm} \text {, které se nacházejí především ve spodní části objektu. } \\
\text { Hraniční kopec je pokryt mechem a lesní humusovou vrst- } \\
\text { vou. Travní drn zde zcela chybí. Na povrchu se vyskytují } \\
\text { drobné náletové dřeviny a jeden středně vzrostlý listnatý } \\
\text { strom. Při jižní straně, která je bliže vystavena poli (louce) je } \\
\text { možné zaznamenat výskyt travin. Průměr základny objektu } \\
\text { činí } 9 \mathrm{~m} \text {, výška } 2,2 \mathrm{~m} \text {. Tvar je oválný. }\end{array}$ \\
\hline č. 7 & Konicko/Jesenec & $\begin{array}{l}\mathrm{N} 49^{\circ} 35^{\prime} 28,60^{\prime \prime} \\
\text { a E } 16^{\circ} 51^{\prime} 20,68^{\prime \prime}\end{array}$ & $\begin{array}{l}\text { Objekt je tvořen převážně kameny, nejčastěji o velikosti do } \\
25 \mathrm{~cm} \text {, méně pak do velikosti } 40 \mathrm{~cm} \text {. Povrch kopce je po- } \\
\text { kryt mechem a humusovou lesní vrstvou. Průměr základny } \\
\text { hraničního kopce je } 10 \mathrm{~m} \text {, jeho výška } 2 \mathrm{~m} \text {. Objekt je oválný, } \\
\text { protažený ve směru Z-V. Na povrchu se vyskytují menší } \\
\text { náletové dřeviny a vzrostlý listnatý strom. }\end{array}$ \\
\hline č. 8 & Konicko/Jesenec & $\begin{array}{l}\mathrm{N} 49^{\circ} 35^{\prime} 28,79^{\prime \prime} \\
\text { a E } 16^{\circ} 51^{\prime} 20,25^{\prime \prime}\end{array}$ & $\begin{array}{l}\text { Objekt je tvořen převážně kameny do velikosti } 30 \mathrm{~cm} \text {, větší } \\
\text { kameny do velikosti } 50 \mathrm{~cm} \text { se vyskytují na povrchu. Plochu } \\
\text { objektu pokrývá také mech a humusová lesní vrstva. Kromě } \\
\text { dvou středně velkých stromů z povrchu objektu nevyrůstají } \\
\text { žádné náletové dřeviny. Prủměr základny činí } 10 \mathrm{~m} \text {, výška } \\
\text { objektu je } 1,9 \mathrm{~m} \text {. }\end{array}$ \\
\hline
\end{tabular}




\begin{tabular}{|c|c|c|c|}
\hline Obj. & Oblast/katastrální území & Zeměpisné souřadnice & Popis \\
\hline č. 9 & Konicko/Jesenec & $\begin{array}{l}\mathrm{N} 49^{\circ} 35^{\prime} 28,85^{\prime \prime} \\
\text { a E } 16^{\circ} 51^{\prime} 19,60^{\prime \prime}\end{array}$ & $\begin{array}{l}\text { Objekt je tvořen zejména drobnými kameny o velikosti } 10 \mathrm{~cm} \\
\text { a dále již méně četnými kameny do velikosti } 50 \mathrm{~cm} \text {. Povrch } \\
\text { objektu pokrývá lesní humusová půda, travní drn zcela chy- } \\
\text { bí. Výška objektu činí } 2,3 \mathrm{~m} \text {, prüměr základny je } 12,2 \mathrm{~m} \text {. }\end{array}$ \\
\hline č. 10 & Konicko/Jesenec & $\begin{array}{l}\mathrm{N} 49^{\circ} 35^{\prime} 29,09^{\prime \prime} \\
\text { a E } 16^{\circ} 51^{\prime} 18,85^{\prime \prime}\end{array}$ & $\begin{array}{l}\text { Objekt je tvořen zejména kameny o velikosti } 15 \mathrm{~cm} \text {. Pokrývá } \\
\text { ho lesní humusová půda a mech. Velikost základny činí } \\
14 \mathrm{~m} \text { a výška objektu je } 2,5 \mathrm{~m} \text {. }\end{array}$ \\
\hline č. 11 & Konicko/Jesenec & $\begin{array}{l}\mathrm{N} 49^{\circ} 35^{\prime} 29,69^{\prime \prime} \\
\text { a E } 16^{\circ} 51^{\prime} 16,92^{\prime \prime}\end{array}$ & $\begin{array}{l}\text { Objekt tvoř́ zejména kameny do velikosti } 20 \mathrm{~cm} \text {. Povrch } \\
\text { pokrývá lesní humusová vrstva. Velikost základny činí } \\
14 \mathrm{~m} \text { a výška objektu je } 1,8 \mathrm{~m} \text {. Na povrchu rostou četné } \\
\text { drobné náletové dřeviny. }\end{array}$ \\
\hline č. 12 & Konicko/Jesenec & $\begin{array}{l}\mathrm{N} 49^{\circ} 35^{\prime} 29,69^{\prime \prime} \\
\text { a E } 16^{\circ} 51^{\prime} 16,97^{\prime \prime}\end{array}$ & $\begin{array}{l}\text { Objekt je tvořen převážně kameny do velikosti } 20 \mathrm{~cm} \text {. } \\
\text { Povrch objektu pokrývá humusová lesní vrstva, která do jihu } \\
\text { přechází v travní porost vyskytující se na blízké louce. Na } \\
\text { povrchu rostou četné drobné náletové dřeviny - převážně } \\
\text { keře. Průměr základy je } 15 \mathrm{~m} \text {, výška objektu činí } 1,8 \mathrm{~m} \text {. }\end{array}$ \\
\hline č. 13 & Konicko/Jesenec & $\begin{array}{l}\mathrm{N} 49^{\circ} 35^{\prime} 30,37^{\prime \prime} \\
\text { a E } 16^{\circ} 51^{\prime} 15,06^{\prime \prime}\end{array}$ & $\begin{array}{l}\text { Objekt je tvořen hlínou a kameny do velikosti } 15 \mathrm{~cm} \text {. Povrch } \\
\text { pokrývá travní drn, který se odlišuje od okolní lesní humu- } \\
\text { sové vrstvy. Na povrchu rostou drobné náletové dřeviny - } \\
\text { keře. Průměr základny objektu činí } 12 \mathrm{~m} \text {, výška je } 1,5 \mathrm{~m} \text {. }\end{array}$ \\
\hline č. 14 & Konicko/Konice & $\begin{array}{l}\mathrm{N} 49^{\circ} 35^{\prime} 15,33^{\prime \prime} \\
\text { a E } 16^{\circ} 51^{\prime} 16,33^{\prime \prime}\end{array}$ & $\begin{array}{l}\text { Objekt je tvořen převážně z hlíny a částečně také kameny } \\
\text { do velikosti } 15 \mathrm{~cm} \text {. Výška objektu je } 1,5 \mathrm{~m} \text {, průměr činí } 5 \mathrm{~m} \text {. } \\
\text { Povrch je pokryt travním drnem, který se odlišuje od okolní } \\
\text { převážně lesní humusové vrstvy. }\end{array}$ \\
\hline č. 15 & Konicko/Konice & $\begin{array}{l}\mathrm{N} 49^{\circ} 35^{\prime} 15,59^{\prime \prime} \\
\text { a E } 16^{\circ} 51^{\prime} 16,79^{\prime \prime}\end{array}$ & $\begin{array}{l}\text { Objekt je tvořen převážně z hlíny a částečně také kameny do } \\
\text { velikosti } 15 \mathrm{~cm} \text {, u severní strany se vyskytuje větší kámen } \\
\text { o velikosti } 70 \mathrm{~cm} \text {. Povrch je pokryt travním drnem, který se } \\
\text { odlišuje od okolní převážně lesní humusové vrstvy. Průměr } \\
\text { objektu při jeho základně je } 10 \mathrm{~m} \text {, výška dosahuje až } 2,2 \mathrm{~m} \text {. }\end{array}$ \\
\hline č. 16 & $\begin{array}{c}\text { Konicko/Brodek } \\
\text { u Konice }\end{array}$ & $\begin{array}{l}\text { N } 49^{\circ} 32^{\prime} 51.774^{\prime \prime} \\
\text { a E } 16^{\circ} 49^{\prime} 4.939^{\prime \prime}\end{array}$ & $\begin{array}{l}\text { Objekt je tvořen převážně hlínou a kameny do velikosti } \\
20 \mathrm{~cm} \text {. Povrch je pokryt humusovou lesní vrstvou - chybí } \\
\text { travní drn. Průměr základny objektu je } 15 \text { m, výška dosahu- } \\
\text { je } 1,8 \text { m. Původně byl kopec zřejmě vyšší, směrem k jihu je } \\
\text { částečně oderodovaný. }\end{array}$ \\
\hline č. 17 & $\begin{array}{c}\text { Konicko/Brodek } \\
\text { u Konice }\end{array}$ & $\begin{array}{l}\text { N } 49^{\circ} 32^{\prime} 50.193^{\prime \prime} \\
\text { a E } 16^{\circ} 49^{\prime} 2.995^{\prime \prime}\end{array}$ & $\begin{array}{l}\text { Objekt tvořen převážně kameny do velikosti } 20 \text { cm a hlínou. } \\
\text { Povrch je pokryt humusovou lesní vrstvou. Ta je na vrcholu } \\
\text { narušena vývratem, který zde zanechal spadlý strom (prav- } \\
\text { děpodobně smrk). Vývrat způsobil poškození, projevující se } \\
\text { propadlým vrcholem kopce a vyvržením kamenů po okrajích } \\
\text { vývratu. Průměr základny je } 7 \text { m, výška } 1,5 \mathrm{~m} \text {. Celková } \\
\text { výška byla negativně ovlivněna vyvrácením stromu, který se } \\
\text { nacházel na povrchu. }\end{array}$ \\
\hline č. 18 & $\begin{array}{c}\text { Konicko/Brodek } \\
\text { u Konice }\end{array}$ & $\begin{array}{l}\text { N 49॰32'49.387" } \\
\text { a E } 16^{\circ} 49^{\prime} 2.540^{\prime \prime}\end{array}$ & $\begin{array}{l}\text { Objekt tvořen převážně z hlíny a kamene do velikosti } 20 \mathrm{~cm} \text {. } \\
\text { Povrch je pokryt humusovou lesní vrstvou. Průměr objektu } \\
\text { je } 5 \mathrm{~m} \text {, výška činí } 1,5 \mathrm{~m} \text {. }\end{array}$ \\
\hline č. 19 & $\begin{array}{c}\text { Konicko/Brodek } \\
\text { u Konice }\end{array}$ & $\begin{array}{l}\mathrm{N} 49^{\circ} 32^{\prime} 55,19^{\prime \prime} \\
\text { a E } 16^{\circ} 48^{\prime} 57,65^{\prime \prime}\end{array}$ & $\begin{array}{l}\text { Objekt tvořen převážně kameny do velikosti } 30 \mathrm{~cm} \text {, hlína } \\
\text { zastoupena jen minimálně. Povrch pokrývá vrstva mechu, } \\
\text { která se drží převážně na povrchu kamenů, a lesní humu- } \\
\text { sovou vrstvou. Objekt má oválný tvar, průměr základny je } \\
10 \mathrm{~m} \text {, výška } 2,2 \mathrm{~m} \text {. }\end{array}$ \\
\hline č. 20 & $\begin{array}{c}\text { Konicko/Brodek } \\
\text { u Konice }\end{array}$ & $\begin{array}{l}\mathrm{N} 49^{\circ} 32^{\prime} 56,33^{\prime \prime} \\
\text { a E } 16^{\circ} 48^{\prime} 52,44^{\prime \prime}\end{array}$ & $\begin{array}{l}\text { Objekt tvořen převážně kameny do velikosti } 30 \mathrm{~cm} \text { a hlí- } \\
\text { nou. Povrch je pokryt lesní humusovou vrstvou. Objekt má } \\
\text { oválný tvar se zploštělou severovýchodní stranou. Průměr } \\
\text { základny činí } 13 \mathrm{~m} \text {, výška objektu je } 2,2 \mathrm{~m} \text {. Od jihu ke kopci } \\
\text { přiléhá kamenný val dlouhý } 20 \mathrm{~m} \text {, široký } 1,5 \mathrm{~m} \text { a vysoký } \\
1 \mathrm{~m} \text {. Jde zřejmě o pozůstatek meze. }\end{array}$ \\
\hline
\end{tabular}




\begin{tabular}{|c|c|c|c|}
\hline Obj. & Oblast/katastrální území & Zeměpisné souřadnice & Popis \\
\hline č. 21 & $\begin{array}{c}\text { Konicko/Brodek } \\
\text { u Konice }\end{array}$ & $\begin{array}{l}\mathrm{N} 49^{\circ} 32^{\prime} 55.086^{\prime \prime} \\
\text { a E } 16^{\circ} 48^{\prime} 40.169^{\prime \prime}\end{array}$ & $\begin{array}{l}\text { Objekt tvořen převážně kameny do velikosti } 20 \mathrm{~cm} \text { a hlínou. } \\
\text { Povrch pokrývá mech, který se koncentruje na povrchu } \\
\text { kamenů, a lesní humusová vrstva. Pokrývají ho také nále- } \\
\text { tové dřeviny a poměrně vzrostlé stromy. Objekt se nachází } \\
\text { v nároží dlouhého pásu drobnějších kamenných hald a valů, } \\
\text { které zřejmě tvořily okraj pole. Průměr základny je } 5 \mathrm{~m} \text {, } \\
\text { výška } 1,5 \mathrm{~m} \text {. }\end{array}$ \\
\hline č. 22 & $\begin{array}{c}\text { Konicko/Brodek } \\
\text { u Konice }\end{array}$ & $\begin{array}{l}\mathrm{N} 49^{\circ} 32^{\prime} 05,24^{\prime \prime} \\
\text { a E } 16^{\circ} 49^{\prime} 27,39^{\prime \prime}\end{array}$ & $\begin{array}{l}\text { Objekt je tvořen převážně kameny do velikosti } 20 \mathrm{~cm} \text {. Horní } \\
\text { část povrchu kryje mech, př́i patě se objevuje lesní humu- } \\
\text { sová půda. Vrchol objektu je narušen vyvrácením stromu, } \\
\text { který po sobě zanechal prohlubeň a volně roztroušené } \\
\text { kameny kolem vývratu. Průmér základny činí } 12,5 \mathrm{~m} \text {, výška } \\
\text { objektu je } 2,5 \mathrm{~m} \text {. }\end{array}$ \\
\hline č. 23 & Konicko/Lipová & $\begin{array}{l}\mathrm{N} 49^{\circ} 32^{\prime} 4.646^{\prime \prime} \\
\text { a E16 } 50^{\prime} 2.404^{\prime \prime}\end{array}$ & $\begin{array}{l}\text { Objekt je tvořen převážně kameny, které jsou částečně po- } \\
\text { kryty mechem. Průměr základny je } 5 \mathrm{~m} \text {, výška činí } 1 \mathrm{~m} \text {. }\end{array}$ \\
\hline č. 24 & Konicko/Lipová & $\begin{array}{l}\mathrm{N} 49^{\circ} 32^{\prime} 5.545^{\prime \prime} \\
\text { a E } 16^{\circ} 50^{\prime} 1.849^{\prime \prime}\end{array}$ & $\begin{array}{l}\text { Objekt tvořen převážně kameny. Průměr základny činí } 6 \text { m, } \\
\text { výška } 1,7 \text { m. Původně byl objekt zřejmě mnohem větší, } \\
\text { ale důsledkem zemědělských prací byl rozorán. Kamenné } \\
\text { pozůstatky se nacházejí roztroušeny po povrchu pole ještě } \\
\text { do vzdálenosti } 10 \text { m od samotného objektu. }\end{array}$ \\
\hline č. 25 & $\begin{array}{c}\text { Šternbersko/Moravský } \\
\text { Beroun }\end{array}$ & $\begin{array}{l}\mathrm{N} 49^{\circ} 49^{\prime} 06,15^{\prime \prime} \\
\text { a E } 17^{\circ} 25^{\prime} 58,85^{\prime \prime}\end{array}$ & $\begin{array}{l}\text { Hraniční kopec dosahující délky } 7,5 \text { m a výšky } 1,5 \mathrm{~m} \text {. Ob- } \\
\text { jekt je tvořen převážně hlínou a kameny do velikosti } 35 \mathrm{~cm} \text {. } \\
\text { Povrch je kryt travním drnem. Hraniční znamení se vysky- } \\
\text { tuje v ploše, kde dosud probíhá intenzivní pastva dobytka. } \\
\text { Pasoucí se dobytek žrejmě poškodil jihovýchodní část } \\
\text { objektu. Z porušené části pochází ojedinělý nález drobného } \\
\text { fragmentu cihly. }\end{array}$ \\
\hline č. 26 & $\begin{array}{c}\text { Šternbersko/Moravský } \\
\text { Beroun }\end{array}$ & $\begin{array}{l}\mathrm{N} 49^{\circ} 49^{\prime} 06,48^{\prime \prime} \\
\text { a E } 17^{\circ} 25^{\prime} 51,24^{\prime \prime}\end{array}$ & $\begin{array}{l}\text { Hraniční kopec dosahující délky } 12 \mathrm{~m} \text { a výšky } 2,2 \mathrm{~m} \text {. Tvořen } \\
\text { je převážně hlínou a kameny do velikosti } 30 \mathrm{~cm} \text {. Pokryt je } \\
\text { travním drnem. Na povrchu, především ve spodní části ob- } \\
\text { jektu, se vyskytují také kameny o velikosti } 50 \mathrm{~cm} \text {. Je možné, } \\
\text { že zde byly umístěny až po vztyčení kopce v souvislosti } \\
\text { s probíhající zemědělskou činností. Objekt byl narušenou } \\
\text { stavbou mysliveckého posedu, který poškodil kopec v jiho- } \\
\text { východní části. V odkryté situaci se mi podařilo nalézt tř́i } \\
\text { fragmenty keramiky rámcově datované do raného novověku, } \\
\text { jeden kus strusky a fragment cihly. }\end{array}$ \\
\hline č. 27 & $\begin{array}{c}\text { Šternbersko/Domašov } \\
\text { u Šternberka }\end{array}$ & $\begin{array}{l}\mathrm{N} 49^{\circ} 43^{\prime} 5.234^{\prime \prime} \\
\text { a E } 17^{\circ} 20^{\prime} 22.008^{\prime \prime}\end{array}$ & $\begin{array}{l}\text { Objekt byl archeologicky zkoumán v roce } 1977 \text {. V součas- } \\
\text { nosti má průměr } 5 \text { metrủ a výšku } 1 \text { m. Pokryt je lesním } \\
\text { porostem, který se nijak neodlišuje od okolního prostředí, } \\
\text { a drobnými náletovými dřevinami. Na okrajích objektu se } \\
\text { nacházejí tři vzrostlé listnaté stromy. }\end{array}$ \\
\hline
\end{tabular}

(polovinou) 14. století na straně druhé. Oba dokumenty se ve svých popisech mírně odlišují. Srovnání vedení hranice ukazuje, že mladší listina již nezmiňuje území na severovýchod od Moravského Berouna, ale přidává prostor mezi Bělkovicemi a Laštanami (CDB II, 412-415 č. 376; CDB V/2, 193-195 č. 599; k dataci listin Berger 1915, 161; Schulz-Hosák 1966, 240-241; Štěpán 1986, 18; obr. 5).

Hranici lesa u Domašova a Lašt’an popisuje starší listina (1220; CDB II, 412-415 č. 376) následovně: „(...) Prima meta circa Domassow super rivulum Olessnik est posita, quae vulgo dicitur kopecz; deinde directe trans montem procedendo sunt metae; quae vulgo hranice dicuntur, usque ad fluvium Dobrnik est meta quae vulgo dicitur kopecz; qui fluvius per ascensum facit metam usque ad suam originem, et ibi est posita meta, quae vulgo dicitur kopecz. Deinde per directum eundo sunt signa, quae vulgo hranicie dicuntur, usque ad viam publicam, quae 


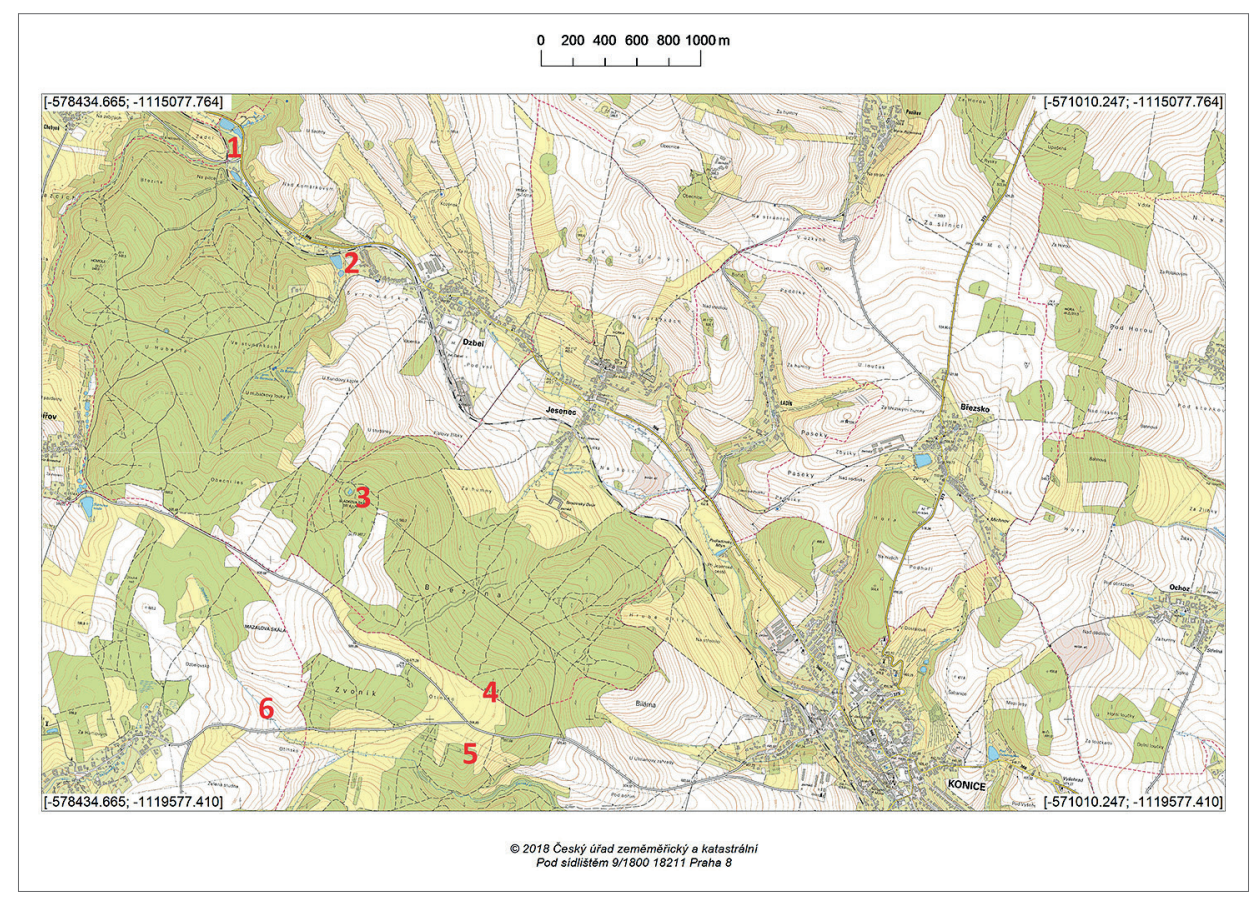

Obr. 4. Severní část územní hranice mezi majetky kláštera Hradisko, Konicí a Lešany podle Bolina-Šlézar 2002. 1 - horní tok Nectavy; 2 - pravděpodobná lokalizace první značky u Studené; 3 - pravděpodobná lokalizace místa Rachowkop; 4 - místo výskytu objektů č. 1-13; 5 - místo výskytu objektů č. 14 a 15; 6 - poloha zaniklé Otíny Lhoty (Otína). Vytvořeno autorem pomocí programu https://geoportal.cuzk.cz/geoprohlizec/.

Abb. 4. Nördlicher Teil der Gebietsgrenzen zwischen den Besitzungen von Kloster Hradisch, Konice und Lešany laut Bolina-Šlézar 2002. 1 - Oberlauf des Flusses Nectava; 2 - wahrscheinliche Lokalisierung der ersten Markierungen bei Studená; 3 - wahrscheinliche Lokalisierung der Stelle Rachowkop; 4 - Vorkommensort der Objekte Nr. 1-13; 5 - Vorkommensort der Objekte Nr. 14 und 15; 6 - Lage der Wüstung Otína Lhota (Otína). Erstellt vom Verfasser mit dem Programm https:// geoportal.cuzk.cz/geoprohlizec/.

vulgo dicitur Rudna czesta; trans viam vero praedictam per directum eundo sunt metae, quae vulgo hranicze dicuntur, trans fluvios Lodimnicie et Lubkow usque ad locum, qui vulgo dicitur Chlum. Post haec directe eundo sunt metae, quae hranicie dicuntur, trans fluvium, qui dicitur Bistrzicie usque ad originem fluvii, qui vulgo dicitur Byssowa. Ab origine Byssowa per directum est ascendendum per signa, quae hranicie dicuntur, usque ad montem, qui dicitur Rosuticze; et sic trans montem Rosuticze, per longum sunt hranicie usque ad fluvium Moravicie. Fluvius vero praedictus per descensum fluens facit metam usque sub montem; qui dicitur Rudeu. Et sic per directum eundo usque ad originem fluvii, qui dicitur Lopemnicze; deinde directe ad originem fluvii Budissow. Postea per directum eundo usque ad originem fluvii, qui dicitur Luboska; deinde per directum ad originem fluvii Stara woda. Postea per directum trans fluvios Scripowy et Bistrzicze usque ad locum, qui dicitur Bychotino pole. Deinde directe per semitam procedendo usque ad fluvium Hraniczni. Fluvius vero praedictus fluens per descensum facit metam usque ad viam quae dicitur Gywowska czesta. Via vero praedicta metam facit usque ad originem fluvii, qui vulgo dicitur Strzelni. Fluvius vero praedictus per descensum fluens facit metam sicut fluit in fluvium Lodimnicie. Praedictus vero fluvius per descensum fluens facit metam usque subtus villas Lassczian monasterii Gradicensis ex una et villam Bilkovicze ex altera parte (...).“

Listina hlásící se k roku 1269 (CDB V/2, 193-195 č. 599) stanovuje hranici tímto způsobem: „(...) scilicet inter viam, per quam itur de Sternow versus Bunowicz, villam monasterii, et aliam 


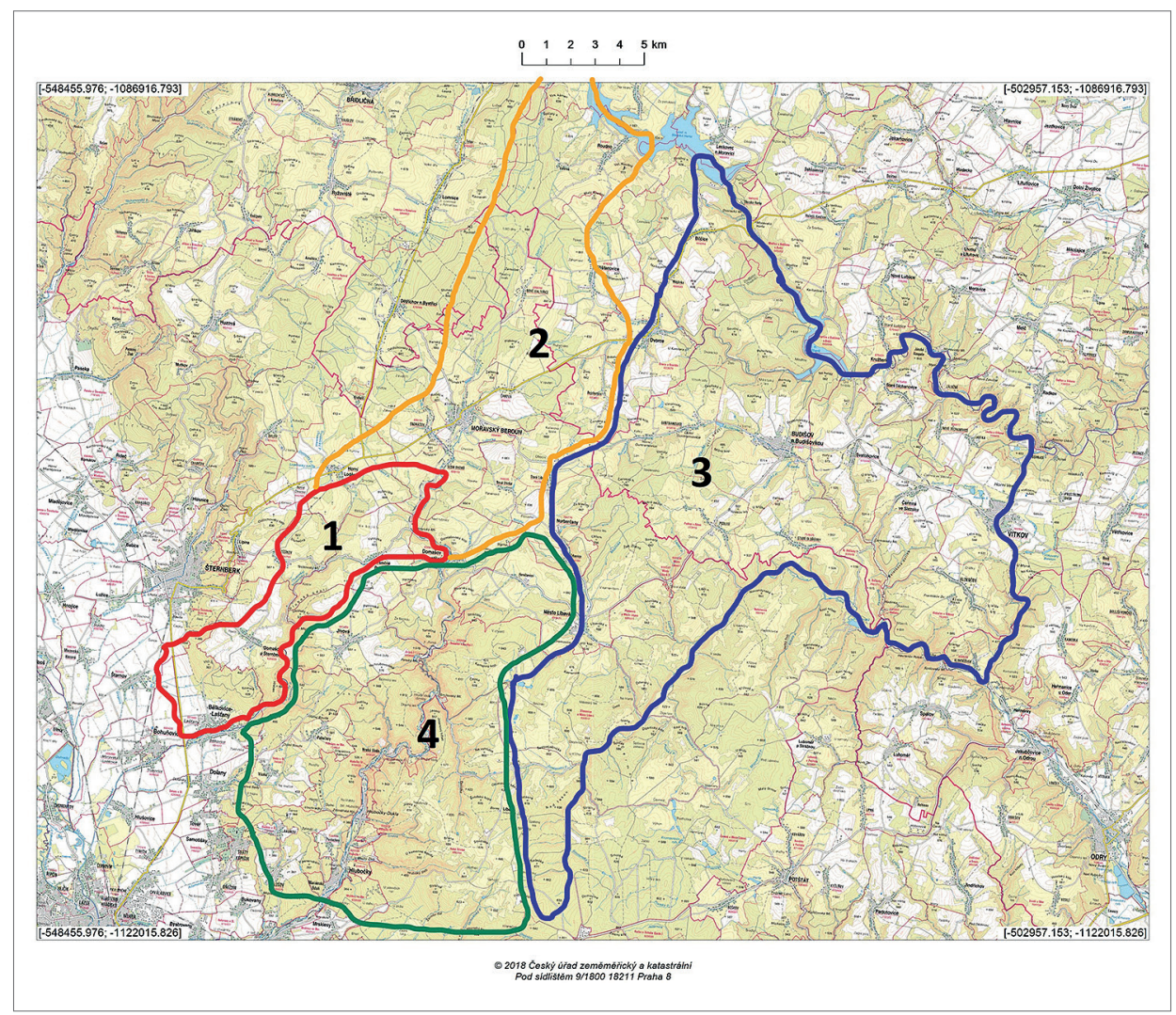

Obr. 5. Rekonstrukce území popsaných v písemných pramenech kláštera podle Novák 2019, 84. 1 - les u Domašova a Lašt’an 1269; 2 - severní území lesa u Domašova a Lašt’an uváděné v listině 1220; 3 - Velká Stř̌elná; 4 - Malá Střelná.

Abb. 5. Rekonstruktion der in den schriftlichen Quellen des Klosters beschriebenen Gebiete laut Novák 2019, 84. 1 - Wald bei Domašov und Lašt'any 1269; 2 - in einer Urkunde von 1220 aufgeführtes Gebiet des Waldes bei Domašov und Lašt’any; 3 - Groß Stř̌elná; 4 - Klein Střelná.

viam, per quam itur de castro Sternberch versus Lasczan, villam monasterii, sunt mete, que vulgo hranicie nuncupantur; deinde directe per fluvium Olesnik, qui facit metam, est eundem usque ad originem suam; et ibi est meta posita, que vulgo dicitur kopecz. Deinde directe trans montem procedendo sunt mete que vulgo hranicie dicuntur, usque ad fluvium Debrnik, ubi est meta, que vulgo dicitur kopecz; qui fluvius per ascensum facit metam usque ad suam originem; et ibi est posita meta, que vulgo dicitur kopecz. Deinde per directum eundo sunt signa, que vulgo hranicie dicuntur, usque ad viam publicam, que vulgo dicitur Rudna ciesta; que via versus orientem facit metam cum signis, que vulgo dicuntur kopci; trans fluvios, scilicet Lodnincie, Hrussowi, Sirz, usque ad pontem fluvii Bistricie, ubi circa pontem positum est signum, qui vulgo dicitur kopecz; fluvius vero Bistricie per descensum fluens facit metam usque ad locum, qui vulgo dicitur Bychotino pole. Deinde directe procedendo per semitam usque ad originem fluvii, qui dicitur vulgo Hraniczni; fluvius vero predictus per descensum fluens facit metam usque ad viam, que vulgo dicitur Gywowska ciesta; via vero predicta metam facit usque ad originem fluvii, qui vulgo dicitur Strelni; fluvius vero predictus per descensum fluens facit metam, sicut fluit in fluvium Lodinnicie; predictus vero fluvius per descensum fluens facit metam usque subtus villas Lasczan monasterii Gradicensis ex una et villam Belkowici ex altera (...).“ Zvýrazněny jsou ty pasáže, které přímo hovoří o hraničních kopcích. 


\section{Profil A-t :}
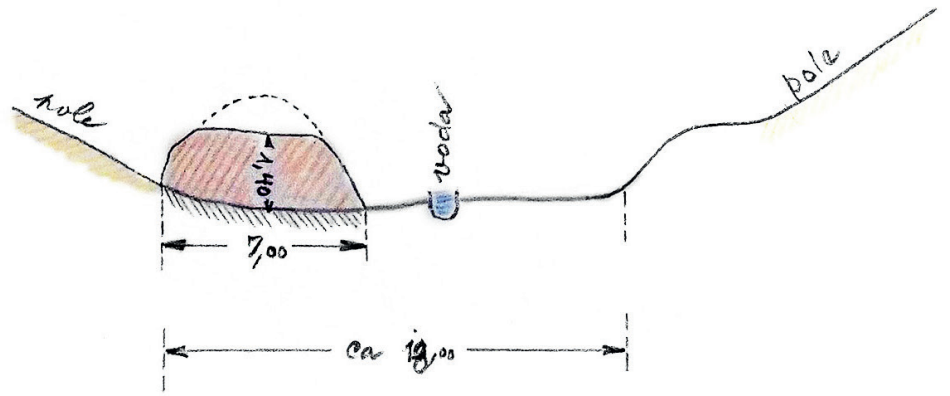

Obr. 6. Situační plánek hraničního kopce u potoka Aleš prozkoumaného archeologickou sondou roku 1977.

Abb. 6. Lageplan des 1977 mit einer archäologischen Sondierungsgrabung untersuchten Grenzhügels am Bach Aleš.

Zájem badatelské generace 19. a 20. století o region popsaný ve sledovaných listinách je možné rozdělit do dvou jazykových proudů. Německy publikující autoři, jakými byli např́íklad E. Hawelka a J. Theimer, se komplexně věnovali osídlení politických okresů Šternberk a Moravský Beroun. Problematice vymezení lesa u Domašova a Laštan se tak logicky nemohli vyhnout. Právě jejich studie patří mezi vůbec první, které toponyma v listinách přiřazují ke skutečným místům v krajině. Položili tak pevný a argumentačně věcný základ pro další badatele (Hawelka 1898, 78-79; Theimer 1930).

Českojazyčný směr byl po roce 1948 a v průběhu 50. let 20. století velmi ovlivněn situací po skončení druhé světové války, kdy došlo ve sledovaných regionech $\mathrm{k}$ odsunu německého obyvatelstva. Popis hranic lesa u Domašova a Lašt’an se objevuje na stránkách posmrtně vydané monografie V. Hrubého o dějinách severní Moravy. Spíše však než na kritické zamyšlení nad vymezeným prostorem kladl autor důraz na prezentaci slovanských pomístních názvů, které mají poskytovat důkaz o tom, že tyto oblasti byly intenzivně obývány již před př́íchodem

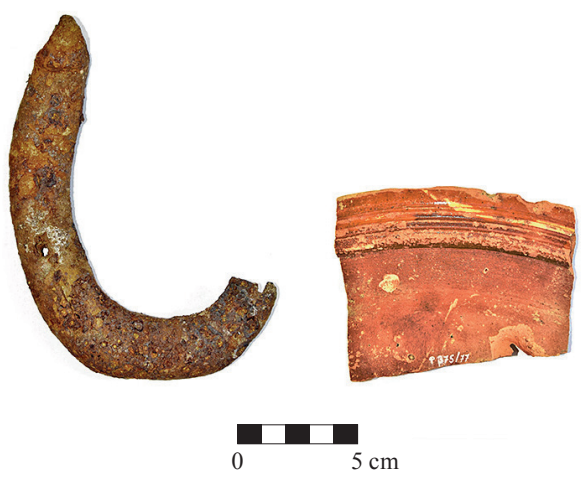

Obr. 7. Zlomek podkovy a stř̌epu ze zkoumaného hraničního kopce. Foto J. Novák, 2019.

Abb. 7. Fragment eines Hufeisens und Scherbe vom untersuchten Grenzhügel. Foto J. Novák, 2019. německých kolonistů. Poměrně silně rezonující protiněmecká nálada se mimo jiné odráží i ve faktu, že autor upozorňuje na „nějaké předchozi německé badatele“, sám je však ale necituje ani na ně nijak neodkazuje. Zůstává otázkou, zda šlo skutečně o autorův záměr, nebo poválečná politická situace ani jiný přístup neumožňovala (Hrubý 1947).

První z badatelů, který skutečně vyrazil do terénu a jmenovaná místa podle znění listiny z roku 1269 fyzicky ohledal, byl A. Ferulík. O svém průzkumu z roku 1951 zanechal krátkou zprávu doplněnou o situační plán obcházeného území (Ferulík 1966, 106-109). Je zároveň prvním autorem, který poukázal na možnost dochování kopcovitých útvarů 


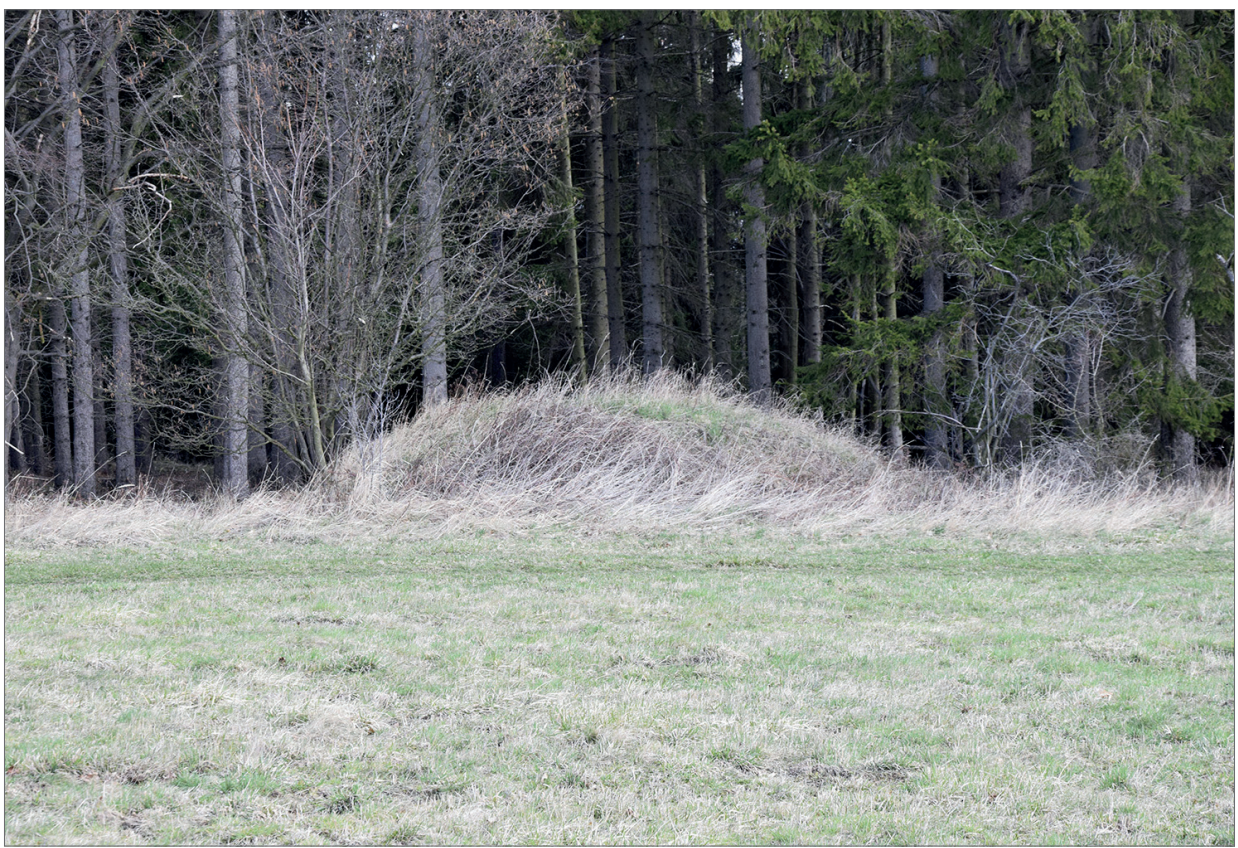

Obr. 8. Fotografie obj. č. 4. Foto J. Novák, 2019.

Abb. 8. Fotografie von Objekt Nr. 4. Foto J. Novák, 2019.

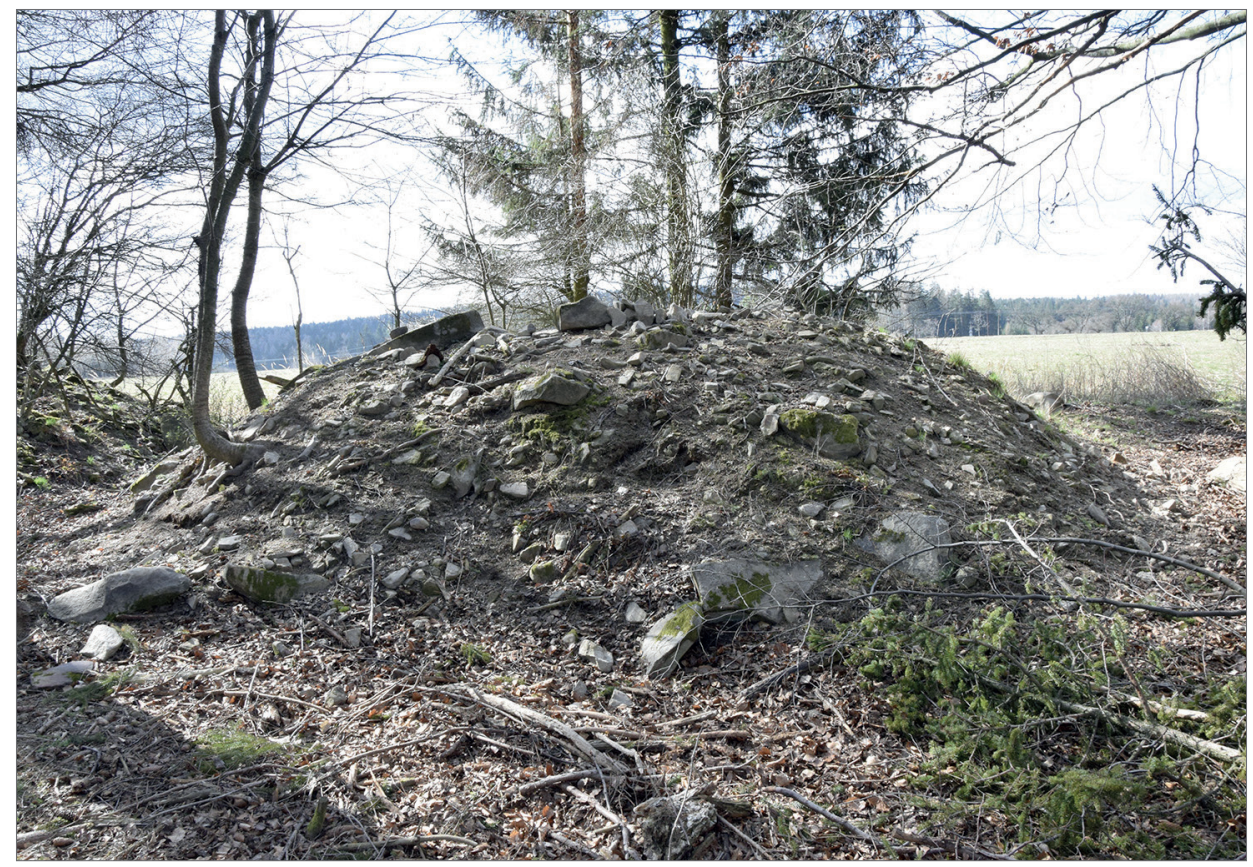

Obr. 9. Fotografie obj. č. 8. Foto J. Novák, 2019.

Abb. 9. Fotografie von Objekt Nr. 8. Foto J. Novák, 2019. 
sloužících k vymezení průběhu hranice v krajině. V souladu se zněním sledovaného pramene zvolil jako výchozí bod své cesty místo mezi Bohuňovicemi a Bělkovicemi. Hranice odtud sledovala směr silnice vedoucí do Šternberka a naproti Štarnovu se odklonila na západ k potoku jménem Aleš (Olessnik). Tato vodoteč tvořila hranici lesa u Domašova a Laštan až k obci Těšíkov. Při horním toku potoka Aleš nalezl A. Ferulík první hraniční kopce. Přestože hovoří o značkách v množném čísle, jejich přesný počet, stejně jako přesnější polohu, neuvádí. Další identifikovaný kopec se vyskytoval u ústí Těšíkovského potoka (Debrnik). Hranice dále postupovala podél vodoteče $\mathrm{k}$ severu přes pozdější ves Těšíkov a následně byla utvářena hraničními znameními na území Horní Loděnice. Autor konstatoval, že v této oblasti byly již v minulosti kopce zničeny poté, co se místní obyvatelé ujali klášterní půdy (zřejmě po zrušení kláštera za Josefa II.). Podařilo se mu však nalézt pozůstatek jedné značky (kopce) v dolním konci Horní Loděnice u cesty, o které se domnívá, že by mohla být Rudnou cestou zmíněnou v listině (Ferulík 1966, 107; Rudnou cestou se zabýval také Bolina 2002, 167-168). Tato komunikace jej postupně přes několik vodotečí dovedla až k přechodu řeky Bystřice v místech, kde se měl podle listiny (1269) nacházet most, tedy někde v jižní části obce Sedm Dvorů. Zde se dle A. Ferulíka nacházelo další hraniční znamení $\mathrm{v}$ podobě kopce. Bystřice pak tvořila hranici směrem na jih až po takzvané Bychotino pole, které leželo v blízkosti později vybudované vesnice Domašov nad Bystřicí. Hranice dále pokračovala na západ do Hraničných Petrovic a odtud na jih po Jívovské cestě. Komunikaci sledovala až asi 800 m hluboko do území Jívové, kde pramenila vodoteč prudce spadající na západojihozápad. Dle A. Ferulíka byla vodoteč pro svůj prudký spád nazvána potok Střelný (Strelni). Ten ústil do Trusovického potoka (Loděnice/Lodinnicie) v místech domašovského mlýna. U pramene potoka Střelný byl nalezen další hraniční kopec. Stejný útvar se vyskytoval i u pramenů severněji položeného potoka, který tvořil hranici tehdejšího katastrálního území Hraničných Petrovic. Údolí této severněji položené vodoteče neslo na starších mapováních pojmenování Tiefer Grund (dnes Hluboké údolí) a vzhledem k tomu, že vodoteč měla rovněž prudký spád, mohla by nést pojmenování Střelný. A. Ferulík si však byl jist, že skutečný potok Střelný pramení až na katastrálním území Jívové a své tvrzení podložil právě přítomností navršeného hraničního kopce. Severnější kopec by podle něj měl být novějšího původu a vznikl v době, kdy se Jívová ujala značné částí klášterních pozemků a vytvořila nové hraniční znamení. Hranici lesa u Domašova tvořil dále Trusovický potok (Loděnice), který se při dolním toku nazýval Bělkovický potok, až k místu mezi Bohuňovicemi a Bělkovicemi (Ferulík 1966, 107-109; o Jívovské cestě v kontextu kolonizace v Nízkém Jeseníku Bolina 2002, 166-168).

Na terénní prospekci hranic lesa u Domašova a Laštan navázal na podzim 1969 a v létě 1971 J. Prucek. Znovu analyzoval klášterní falzum (1269) a mírně poupravil Ferulíkovo vedení hranice mezi Těšíkovem a Domašovem u Šternberka. Během průzkumu se mu podařilo znovu objevit jen jeden hraniční kopec, který byl následně zkoumán archeologicky (Prucek 1972, 10; Dohnal-Morav 1978, 1-2).

Zatímco A. Ferulík a J. Prucek se zabývali vymezením lesa podle falza údajně z roku 1269 , $\mathrm{k}$ podrobnějšímu rozboru mírně odlišného průběhu hranice podle listiny s vročením 1220 přikročili až J. Schulz a L. Hosák. Přestože se ke své rekonstrukci odhodlali jen na základě analýzy předchozí literatury, rozboru písemného pramene a studia starých map a pomístních názvů, došli k poměrně přesvědčivým výsledkům (Schulz-Hosák 1966, 238-240; obr. 5). Jejich popis začal u hraničního kopce, který se nacházel u pramene potoka Aleš (Olessnik). Hranice dále pokračovala k potoku Dobrnik a jeho tok sledovala až k prameni. Autoři se domnívali ve shodě se závěry E. Hawelky, K. Bergera a J. Theimera, že jde o Sprchový potok, který pramení severovýchodně od Lipiny (Schulz-Hosák 1966, 239; Hawelka 1898, 78; Berger 1915, 134; Theimer 1930, 50-51). Osobně se však spíše přikláním k variantě A. Ferulíka, který vodoteč ztotožnil s Těšíkovským potokem (Ferulík 1966, 107). Od pramene Dobrniku hranice směřovala k Rudné cestě, kterou vzhledem k popisu úseku „trans viam“ překročila. Po překročení komunikace šla přes Trusovický potok (Lodimnicie) a Lubkow, o kterém se J. Schulz a L. Hodák domnívali, že označoval východní zdrojnici jmenované vodoteče. Dále pokračovala k blíže neidentifikovatelnému místu 

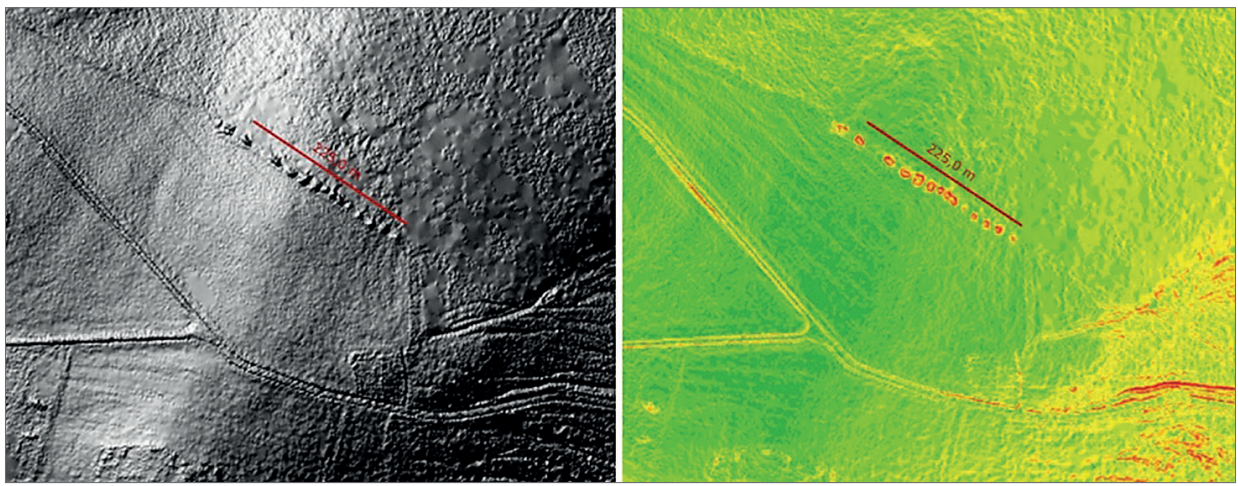

Obr. 10. Lidarový snímek a analýza výškopisných dat obj. č. 1-13. Vytvořeno autorem pomocí programu https://ags.cuzk. $\mathrm{cz} / \mathrm{dmr} /$.

Abb. 10. Lidar-Aufnahme und Analyse der Geländeoberflächendaten der Objekte Nr. 1-13. Erstellt vom Verfasser mit dem Programm https://ags.cuzk.cz/dmr/.

Chlum, které se však muselo nacházet někde mezi Horní Loděnicí a řekou Bystřicí. Autoři, opět s odvoláním na pasáž „(...) trans fluvium, qui dicitur Bistrzicie (...)“, konstatovali, že hranice šla přes jmenovanou vodoteč k pramenům řeky Byssowa a k hoře Rosuticze (Schulz-Hosák 1966, 239). Řeku Byssowa nedokázali jednoznačně identifikovat, ale domnívali se, že by se mohlo jednat o vodoteč pramenící severně od Nových Valteřic, případně o potok (zřejmě Rýžovník), který pramení pod Slunečnou a teče k severu, kde se pod Novou Plání před výstavbou vodní nádrže Slezská Harta vléval do Moravice. Horu Rosuticze již němečtí badatelé lokalizovali jako vrch Slunečná, nicméně J. Schulz a L. Hosák dodali, že za Rosuticzi je nutné považovat celý táhlý hřeben dnešní Slunečné, jež se skládá z několika vrcholů. Od Slunečné hranice směřovala k Moravici a dále sledovala její tok (dnes pod hladinou Slezské Harty) až k hoře Ruden, čili Velkému Roudnému (Schulz-Hosák 1966, 239-240). Hranici dále tvořily prameny Lopníku (Lopemnicze), Budišovky (Budissow), Libavského potoka (Luboska) a Staré vody (Stara woda), kterou J. Schulz a L. Hosák ztotožnili s Lazským potokem. Další průběh je dle autorů velmi nejasný. Hranice zřejmě pokračovala od pramene Lazského potoka k západu, směrem k Bystřici. V tomto prostoru se nejspíše nacházel i jmenovaný Scripow. Přesněji se jim nedaří lokalizovat ani Bychotino pole a jen přibližně jej kladou na pravý břeh řeky Bystřice. Hranici dále měla utvářet cesta až k potoku Hraniczni a Jívovské cestě. Po ní vedla hranice k prameni potoka Strzelni a k jeho ústí do Trusovického potoka, který byl hranicí až k Laštanům a Bělkovicím. Potok Strzelni ztotožnili s vodotečí, která pramení pod vrchem Jedová nedaleko silnice z Dolan do Jívové, teče k západu a vlévá se do Trusovického potoka. Jejich popis hranice od Bychotina pole se tedy mírně odlišuje od přesvědčivých závěrů A. Ferulíka a následně i J. Prucka podpořených nálezy hraničních kopců (Schulz-Hosák 1966, 240).

\section{Objekty lokalizované na území lesa u Domašova a Lašt’an}

Shodně se zněním listinného falza (1220) jsem svou terénní prospekci zahájil u pramene potoka Aleš. Pohled do aktuální topografické mapy ukazuje, že jmenovaná vodoteč má dvě zdrojnice, které se spojují u západního konce vesnice Domašov u Šternberka. Právě u západní zdrojnice byl v roce 1977 archeologicky prozkoumán hraniční kopec. Jeho pozůstatky jsem dokázal ještě v terénu částečně rozpoznat (tab. 2, obj. č. 27). Objekt se nachází asi 30 m jihozápadně od prameniště vodoteče, která tvoří západní zdrojnici v písemných pramenech jmenovaného potoka Aleš. Kolem vodního toku je zachován lesní porost, jenž směrem k jihu s prohlubujícím se údolím vodoteče 
houstne. V současnosti má hraniční kopec průměr $5 \mathrm{~m}$ a výšku $1 \mathrm{~m}$ a je pokryt humusovou lesní vrstvou a drobnými náletovými dřevinami.

V dalším vedení hranice se shoduji se závěry A. Ferulíka, J. Schulze a L. Hosáka až k místu, kde hranice překračuje řeku Bystřici. Odtud měla pokračovat k prameni potoka Byssowa a dále přes vrchol Slunečné. Autoři předpokládali, že potok Byssowa by mohl odpovídat vodoteči, která pramení severně od Nových Valteřic. Pravděpodobně měli na mysli vodoteč jménem Důlní potok, jehož pramen se nachází 1,5 km na jihozápad od vrcholu Malého Roudného (771,4 m n. m.). Pokud by to však byla pravda, musela by se hranice stáčet zpět od pramene k jihozápadu na svahy Nízkého Jeseníku a přes vrchol Slunečné (Rosuticze). Pravděpodobnější je, že hranice si od překročení Trusovického potoka držela severovýchodní směr, překročila řeku Bystřici a dále směřovala přes hřeben Nízkého Jeseníku. Jmenovanou vodoteč Byssowa je pak potřeba hledat severozápadně od Moravského Berouna a jižně od vrcholu Slunečné (800 m n. m.). Právě v tomto prostoru se nachází několik možných vodotečí, které by zapadaly do zvoleného konceptu. Přibližně $\mathrm{v}$ těchto místech se mi rovněž podařilo lokalizovat dva hraniční kopce (k. ú. Moravský Beroun, obj. č. 25, 26; obr. 11, 12). Nacházejí se přibližně 2,8 km severozápadně od Moravského Berouna, 150 m (obj. č. 25) a 250 m (obj. č. 26) východně od kóty 683,6 m. Mapa 1. i 2. vojenského mapování ukazuje, že tyto kopce ze západu míjela komunikace, která stoupala od Moravského Berouna a pokračovala dále kolem vrcholu Slunečné $(800 \mathrm{~m} \mathrm{n}$. m.). Oba objekty byly tvořeny převážně hlínou, potvrzena však byla také přítomnost kamenů o velikosti v rozmezí 30 až $50 \mathrm{~cm}$ pokrytých vrstvou travního drnu. Výška prvního hraničního kopce (obj. č. 25) činí 1,5 m, průměr základny dosahuje délky 7,5 m. Druhý hraniční kopec (obj. č. 26) je vysoký 2,2 m s průměrem základny $12 \mathrm{~m}$. Objekt byl narušenou stavbou mysliveckého posedu, který poškodil kopec v jihovýchodní části. $V$ odkryté situaci se mi podařilo nalézt tři fragmenty keramiky rámcově datované do raného novověku, jeden kus strusky a fragment cihly (obr. 13).

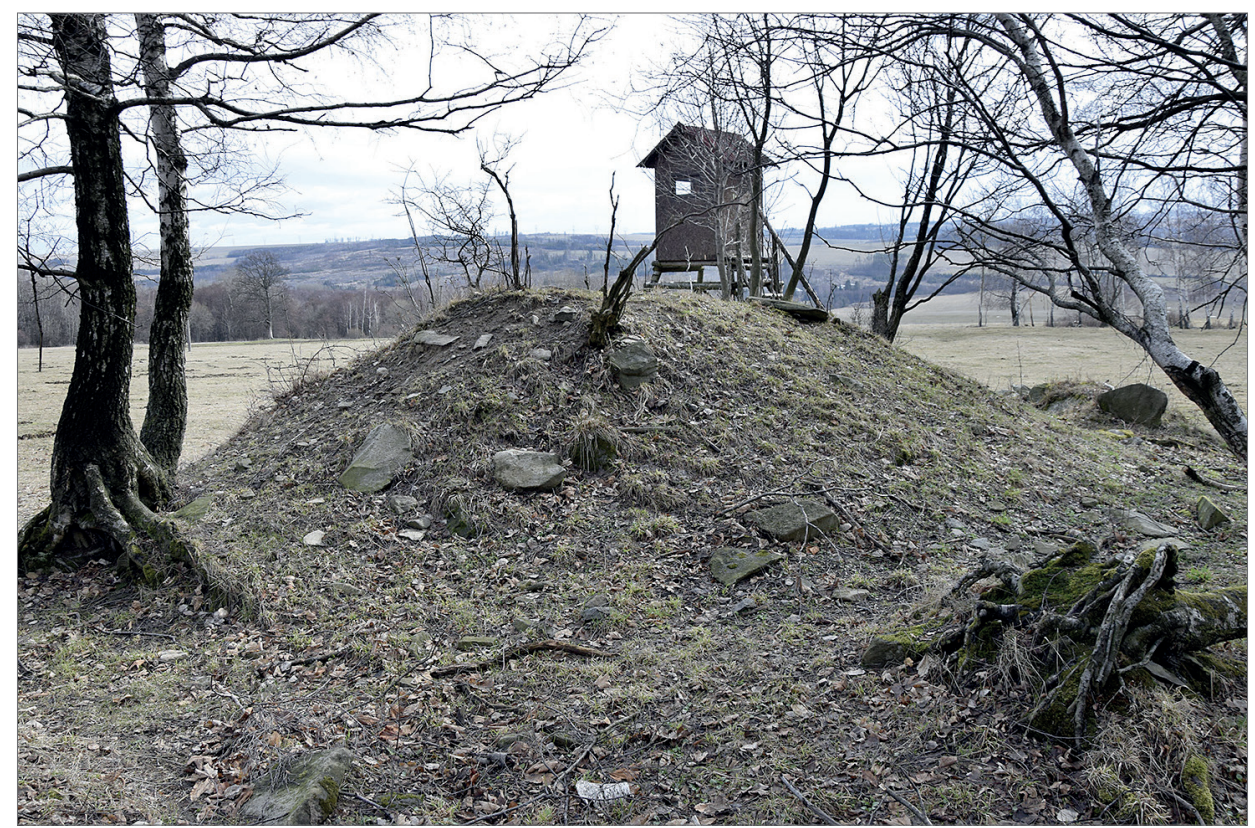

Obr. 11. Fotografie obj. č. 26. Foto J. Novák, 2019.

Abb. 11. Fotografie von Objekt Nr. 26. Foto J. Novák, 2019. 


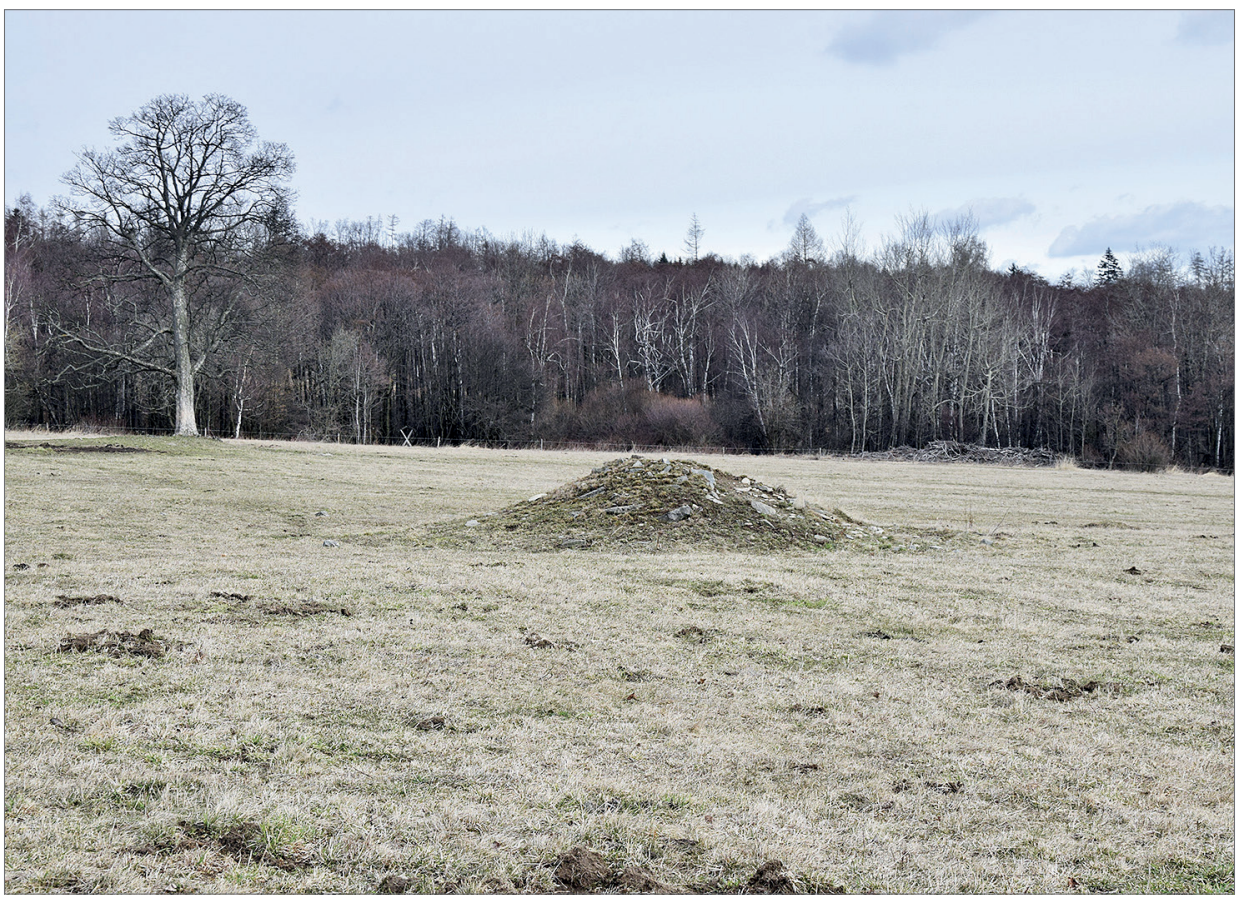

Obr. 12. Fotografie obj. č. 25. Foto J. Novák, 2019.

Abb. 12. Fotografie von Objekt Nr. 25. Foto J. Novák, 2019.
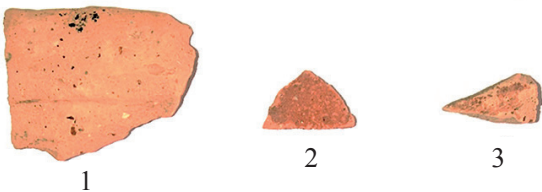

2

3

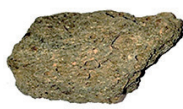

4
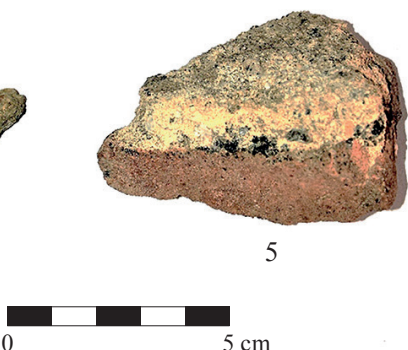

Obr. 13. Nálezy z obj. č. 25; 1-3 - fragmenty keramiky; 4 struska; 5 - zlomek cihly.

Abb. 13. Funde aus Objekt Nr. 25; 1-3 - Keramikfragmente; 4 - Schlacke; 5 -Ziegelbruchstück.
Závěr

Možnosti rekonstrukce a identifikace přirozených i umělých hraničních bodů podle písemných pramenů kláštera Hradisko u Olomouce ukázaly, že v terénu je stále částečně možné lokalizovat jak přirozené, tak i umělé hraniční body, především takzvané kopce.

Za oblast, která nabízí i do budoucna největší potenciál, je možné považovat celou severní část Drahanské vrchoviny, tedy takzvané Horní panství kláštera Hradisko, a území lesa u Domašova a Lašt’an. Jelikož se jedná o území s výrazným zastoupením lesů, je zde pravděpodobnost dochování hraničních znamení nejvyšší. Na opačné straně pomyslného měřítka stojí Olomoucko, Hranicko a území lesa Velká Střelná, kde jsou šance na lokalizaci hraničních kopců velmi mizivé. Problematická je zde i jen prostá identifikace pomístních názvů. Nakonec ale i zde bylo možné provést celkovou rekonstrukci zejména přirozených hraničních bodů (blíže k oblastem, které nebyly v tomto článku charakterizovány, Novák 2019, 66-72, 89-100). 
V rámci terénní prospekce se podařilo v terénu lokalizovat a zdokumentovat celkem 27 hraničních kopců. Jen tři z nich se nacházely na území, které písemné prameny popisují jako les u Domašova a Laštan. Zbylé byly lokalizovány na linii, která oddělovala majetky kláštera na jedné straně a Konici a Lešany na druhé straně. Obecně lze identifikované hraniční kopce charakterizovat jako objekty tvořené kameny, hlínou, nebo kombinací obojího. Velikostně u nich lze pozorovat dvě základní kategorie. První s průměrem základny objektů kolem $5 \mathrm{~m}$ a výškou do 1,5 m. Druhou s průměrem základny 10 až 15 m a výškou od 1,8 do 2,2 m. Podařilo se prokázat i zvyk vkládání svědků (signa oculta) do objektů. Je doložen archeologickým výzkumem hraničního kopce na katastrálním území Domašova u Šternberka v roce 1977 a také materiálem, který se podařilo najít v jednom z poškozených hraničních znamení na katastrálním území Moravského Berouna.

Realizovaný výzkum jasně ukázal, jak velký potenciál má problematika hranic a hraničení z pohledu spolupráce terénního výzkumu (archeologie) a analýzy písemných pramenů (historie). Lokalizované objekty mají vysokou vypovídací hodnotu nejen pro možnosti sledování průběhu vedení hranice, ale také pro výzkum s celou problematikou souvisejících hraničních sporů, kterým v příspěvku nebyla věnována až tak velká pozornost (blíže Novák 2019, 29-38). Z památkového hlediska se jedná o dosud přehlížené objekty, které z krajiny mizely a mizí nejen v důsledku lidských aktivit, ale i vlivem přírodních živlů (ke stavu dochování viz tab. 2).

Př́ispěvek vznikl za podpory MŠMT ČR udělené UP v Olomouci (IGA_FF_2019_011) v rámci projektu Společnost v historickém vývoji od pravěku po moderní věk V.

\section{Prameny a literatura}

BENEŠ, J.-LUTOVSKÝ, M., 1997: Mohylovité útvary u Nebahov na Prachaticku, Výběr. Časopis pro historii a vlastivědu jižních Čech 34, 219-221.

BERGER, K., 1915: Der Grosse Strelnawald, Zeitschrift des Vereines für Geschichte Mährens und Schlesiens 19, 125-174.

BISTŘICKÝ, J., 1993: Zakládací listiny kláštera Hradiska u Olomouce a počátky české panovnické listiny Die Gründundsurkunden des Klosters Hradisch bei Olmütz und die Anfänge der böhmischen Herrscherurkunde, VVM 45, 131-136.

BOHÁČ, Z., 1974: Újezdy a Lhoty. Příspěvek k dějinám osídlení středověkých Čech - Orte Namens Újezd und Lhota. Ein Beitrag zur Siedlungsgeschichte Böhmens im Frühmittelalter, HG 12, 3-25.

BOLINA, P., 2002: Pokus o modelové řešení některých problému kolonizace a vzniku hradů v Nízkém Jeseníku - Der Versuch, einige mit der Kolonisation und mit der Entstehung der Burgen in Nízký Jeseník zusammenhängende Probleme mit Hilfe Modellsituationen zu lösen, AH 27, 163-178.

BOLINA, P.-ŠLÉZAR, P., 2006: K problematice falz vzniklých při majetkových sporech hradišt’ského kláštera na severu Drahanské vrchoviny - Zur Problematik der bei Eigentumsstreitigkeiten des Klosters Hradischt im Norden der Drahaner Höhe entstandenen Fälschungen, ČMM 125, 307-342.

BURIAN, B., 1939: Konický okres. Vlastivěda Moravská. Brno.

CDB II: Codex diplomaticus et epistolaris regni Bohemiae II, 1198-1230 (Friedrich, G., ed.). Pragae 1912

CDB VI/1: Codex diplomaticus et epistolaris regni Bohemiae V/1, 1253-1266 (Šebánek, J.-Dušková, S., edd.). Pragae 1974.

CDB V/2: Codex diplomaticus et epistolaris regni Bohemiae V/2, 1267-1278 (Šebánek, J.-Dušková, S., edd.). Pragae 1981

DOHNAL,V.-MORAV, K., 1978: Nálezová zpráva - zjištovací sonda hraniční značky na území Domašova u Šternberka, ulož. ve Vlastivědném muzeu Olomouc (př. č. 375/77).

DOHNAL, M.-ŠÍDA, P., 2007: Historické způsoby značení pozemkových hranic a problematika tzv. mohylovitých útvarů - Historical methods for marking territorial boundaries and the problem of „tumulus“ formations, ASČ 11, 635-652. 
DOLEŽEL, J., 2003: K etnické struktuře středověké kolonizace Drahanské vrchoviny - Zur ethnischen Struktur mittelalterlichen Kolonisation des Drahanská vrchovina (Drahaner Höhe), AH 28, 123-173.

DOLISTA, K., 1971: Ještě k listinám hradišt'ského kláštera z roku 1078, ČsČH 19 (69), 111-118.

ELBEL, P., 2002: Hospodářské zázemí kláštera Hradiště u Olomouce v 11. a 12. století - The Economic Base of the Monastery Hradiště u Olomouce in the Eleventh and Twelfth Centuries. In: Ve stopách sv. Benedikta (Jan, L.-Obšusta, P., edd.), 39-56. Brno.

FERULÍK, A., 1966: Hranice domašovského lesa, VVM 18, 106-109.

GEISLEROVÁ, K.-PARMA, D. a kol., 2018: Výzkumy 2011-2016 - Ausgrabungen 2011-2016. Brno.

HAWELKA, E., 1898: Die Besiedlung des politischen Bezirkes Sternberg, Zeitschrift des Vereines für Geschichte Mährens und Schlesiens 2, 72-122.

HIKL, R., 1962: Cesta Konická a otázky kolem ní, Zprávy Vlastivědného ústavu v Olomouci 98, 1-8.

HOSÁK, L., 1969: Počátky a vývoj města do válek husitských. In: Hranice: dějiny města I. Od nejstarších dob do války třicetileté (Hosák, L.-Indra, B.-Jašková, M., edd.), 23-37. Hranice.

HRUBÝ, F., 1947: Severní Morava v dějinách. Brno.

JANIŠ, D.-ŠENKÝŘOVÁ, J., 2004: Hranice statků a pozemků - jejich zachycení v písemných (právních) pramenech - Grenze der Güter und Grundstücke - ihre Dokumentation in den schriftlichen (juristischen) Quellen, AH 29, 193-202.

KIERSNOWSKI, R., 1960: Znaki graniczne w Polsce średniowiecznej, Archeologia Polski 5, 257-289.

KLÁPŠTĚ, J., 2012: Proměna českých zemí ve středověku. 2. vyd. Praha.

MALINIAK, P., 2010: The use of border signs in the Carpathian region: Contribution to the understanding of borders in the Middle and Early Modern Age. In: Historiography in Motion (Holec, R.-Kožiak, R., edd.), 62-76. Bratislava - Banská Bystrica.

MARKOVÁ, M., 2008: Vymezování hranic a jejich značení v př́íodě ve středověku. In: Regiony - časoprostorové průsečíky? (Šimůnek, R., ed.), 98-106. Praha.

- 2017: Hranice a hraničení ve středověké stř̌ední Evropě - Borders and their delineating in medieval Central Europe. Disertační práce, ulož. na FF UK, Praha.

MACKERLE, J., 1957: Provincie Úsobrnská, Severní Morava 2, 23-26.

- 1958: Letopis města Jevíčka. Brno.

MODZELEWSKI, K., 2010: Barbarská Evropa. Praha.

NOVÁK, J., 2019: Vymezování panství kláštera Hradisko u Olomouce ve středověku - The demarcation of the dominion of the Hradisko monastery near Olomouc in the Middle Ages. Diplomová práce, ulož. na FF UP, Olomouc.

PINKAVA, V., 1909: O některých podvržených listinách kláštera Hradišt'ského, ČMM 33, 392-400.

- 1993: Dějiny města Konice I. Konice.

PIŠTĚLÁK, J., 2003: Úsobrno a úsobrnská provincie. In: Sborník muzea Blansko 2003, 3-21. Blansko.

PRUCEK, J., 1972: „... meta que vulgo dicitur kopecz“, Zprávy vlastivědného ústavu v Olomouci 154, 8-10.

RICHTER, V., 1955: Krajina Moravského Třebovska, ČSPS 63, 40-49.

SCHULZ, J.-HOSÁK, L., 1966: Př́́spěvek k lokalizaci lesa Střelná, VVM 18, 235-244.

SLIVKA, M., 2004: Hranice v mentálnom chápání středovekého člověka - Grenze in der Mentalwahrnehmung des mittelalterlichen Menschen, AH 29, 9-36.

ŠEBÁNEK, J.-DUŠKOVÁ, S., 1952: Kritický komentář k moravskému diplomatáři. Zpracování látky z III. svazku Bočkova moravského kodexu. Praha.

- 1953: Studie k českému diplomatáři, SPFFBU 2, 262-307.

- 1956: Česká listina doby přemyslovské (Listina nižších feudálů duchovních - listina feudálů světských) Die Urkunde der Přemyslidenzeit in Böhmen (Die Urkunde der niederen geistlichen Feudalen - die Urkunde der niederen Laienfeudalen), Sborník archivních prací 6, 136-211.

ŠEDIVÝ, J., 2018: Historické nápisy a ich nosiče. Bratislava.

ŠÍDA, P.-PROSTŘEDNÍK, J., 2006: Změny v zemědělském využívání podhůří Jizerských hor ve světle archeologických a etnografických pramenů, Z Českého ráje a Podkrkonoší 19, 104-120.

ŠLÉZAR, P., 2007: Sády, kopy a výprask „,na pamětnou“. Hranice ve středověké krajině Drahanské vrchoviny - Grenzsteine, Erdhaufen und Prügel zum Gedächtnis. Grenzen in der mittelalterlichen Region des Drahaner Höhenzugs, VVM 59, 155-161. 
ŠTĚPÁN, V., 1986: Listina hradišt’ského kláštera údajně z roku 1269, Z dějin hutnictví 15, 18-41.

TEIGE, J., 1895: Zpráva o pramenech dějin kláštera Hradišt'ského u Olomouce (až do r. 1300), Věstník Královské české Společnosti nauk v Praze 12, 1-80.

TEPLÝ, J., 1997: Př́íspěvek k problematice okrsku zvaného v listinných pramenech „circuitus“ - Beitrag zur Problematik des Gebietes, das in den Urkundenquellen „circuitus“ genannt wurde, Východočeský sborník historický 6, 9-32.

THEIMER, J., 1930: Heimatbuch für den Bezirk Bärn. Beroun.

VELÍMSKÝ, T., 1998: Trans montes, ad fontes! (Přes hory k pramenům!). K roli újezdů při středověké kolonizaci středních a vyšších poloh na území severozápadních Čech - Trans montes ad fontes! Zur Deutung der nittelalterlichen Kolonisation von mittel- und hochgelegengen Gebieten in Norswestböhmen. Most.

WIHODA, M., 2011: Klášter Panny Marie a svatého Jiří ve Střelné. Pokus o návrat k jednou již spatřenému. In: Co můj kostel má, nemůže kníže odníti. Věnováno Petru Sommerovi k životnímu jubileu (Doležalová, E.-Meduna, P., edd.), 138-144. Praha.

ZAORAL, P., 1968: K zakládací listině hradišt’ského kláštera z roku 1078, ČsČH 16 (66), 275-283.

\section{Zusammenfassung}

\section{Hügelartige Gebilde aus Lehm und Stein als Mittel zur Absteckung von Gebietsgrenzen in den schriftlichen Quellen des Klosters Hradisch bei Olmütz}

Zur Gruppe der Ende 13. und Anfang 14. Jahrhundert entstandenen Fälschungen von Kloster Hradisch zählen sechs Urkunden, in denen die Grenzen der klösterlichen Ländereien in den Regionen Konice, Hranice, Šternberk, Olmütz und im Großen Střelná-Wald detailliert beschrieben werden. Neben natürlichen Grenzpunkten werden in den Urkunden auch sogenannte Hügel erwähnt. In der Region Šternberk wurden diese Objekte in den fünfziger, sechziger und siebziger Jahren des vergangenen Jahrhunderts noch erkannt, als auch eine bis dahin für Mähren einzigartige archäologische Grabung an einem der Grenzhügel durchgeführt wurde. Seitdem hat die Historiographie ihnen keine nähere Beachtung mehr geschenkt. Eine 2017-2019 durchgeführte und auf eine mögliche Rekonstruktion und Identifizierung natürlicher und künstlicher Grenzpunkte gemäß dem Wortlaut von aus dem Kloster Hradisch stammenden schriftlichen Quellen ausgerichtete Geländeprospektion hat gezeigt, dass es immer noch möglich ist, im Gelände sowohl natürliche, als auch künstliche (Hügel) Grenzpunkte zu finden.

Dabei handelt es sich im Grunde genommen um mit Lehm, manchmal auch mit Steinen aufgeschüttete Hügel, die von einer vor Erosion schützenden Grasnarbe bedeckt werden. Gegen ein Ausschwemmen des Grenzzeichens konnte auch eine Verkleidung mit Holzbalken helfen. Damit man solche künstlich geschaffenen Grenzmarkierungen von den natürlichen Unebenheiten des Geländes unterscheiden kann, hat man Markierungen - signa oculta - in die Hügel eingebettet, die als eindeutiger Identifikator dienten, der bestätigte, dass es sich um ein zur Absteckung einer Grenze bestimmtes Mittel handelt. Bei den absichtlich in die Hügel eingebetteten Gegenständen konnte es sich beispielsweise um Schmiedeschlacke, Kohlentöpfe (Kohlen), Holzkohle, Ziegeln, Eicheln, Glas, Keramikscherben, Kalk, Münzen und weitere Metallgegenstände handeln.

Im Rahmen der Geländeuntersuchung gelang es, insgesamt 27 Grenzhügel zu finden und zu dokumentieren. Nur drei von ihnen befanden sich in dem Gebiet des sog. Waldes bei Domašov und Lašt’any. Die übrigen Objekte (24) befanden sich auf einer Linie, welche die Besitzungen des Klosters auf der einen Seite und Konice und Lešany auf der anderen Seite voneinander trennte. Die identifizierten Grenzhügel wurden aus Steinen, Lehm oder aus einer Kombination von beidem errichtet. Größenmäßig können zwei Grundkategorien beobachtet werden. Die erste mit einem Durchmesser der Grundfläche von ca. $5 \mathrm{~m}$ und einer Höhe von 1,5 m. Die zweite mit einem Durchmesser der Grundfläche von 10-15 m und einer Höhe von 1,8 bis 2,2 m. Nachgewiesen wurde auch der Brauch der Einbettung von Zeugen (signa oculta) in das Objekt. Dokumentiert 
wurde er 1977 durch eine archäologische Grabung an einem Grenzhügel im Katastergebiet von Domašov bei Šternberk, und durch das Material, das im Jahr 2019 in einem der beschädigten Grenzhügel im Katastergebiet von Moravský Beroun entdeckt wurde.

Die realisierte Grabung hat klar gezeigt, welch großes Potenzial die Untersuchung der Problematik von Grenzen und der Anrainung mittels einer Geländeuntersuchung (Archäologie) bei gleichzeitiger Analyse von schriftlichen Quellen (Geschichte) hat. Die lokalisierten Objekte haben nicht nur hinsichtlich der Beobachtung des Verlaufs von Grenzführungen einen hohen Aussagewert, sondern auch für die Erforschung der mit Grenzstreitigkeiten zusammenhängenden Problematik. Aus Sicht des Denkmalschutzes handelt es sich um bislang übersehene Objekte, die in der Landschaft untergingen und nicht allein infolge menschlicher Aktivitäten verschwinden, sondern auch durch die Einwirkung der Naturelemente.

Der vorliegende Beitrag entstand im Rahmen des vom Ministerium für Schulwesen, Jugend und Leibeserziehung der Tschechischen Republik an die Palacký-Universität vergebenen Förderprojekts (IGA_FF_2019_011), Die Gesellschaft in der historischen Entwicklung von der Urzeit bis zum Zeitalter der Moderne V.

Mgr. et Mgr. Jakub Novák, Katedra historie Filozofické fakulty Univerzity Palackého v Olomouci, Na Hradě 5, 77900 Olomouc, Česká republika,jakub.novak04@upol.cz 
